\title{
A Survey of the Status of Orthodontics Among Organizations Within the World Federation of Orthodontists
}

\section{Neil C Kessel, DDS}

\begin{abstract}
A thesis submitted to the faculty of the University of North Carolina at Chapel Hill in partial fulfillment of the requirements for the degree of Master of Science in the School of Dentistry (Orthodontics).
\end{abstract}

\section{Chapel Hill}

2013

Approved by:

H. Garland Hershey, Jr., DDS, MS

Ceib Phillips, MPH, PhD

Teresa Edwards, MA 
(C)2013

Neil C Kessel

ALL RIGHTS RESERVED 


\begin{abstract}
NEIL C. KESSEL: A Survey of the Status of Orthodontics Among Organizations Within the World Federation of Orthodontists

(Under the direction of Dr. H. Garland Hershey, Jr.)
\end{abstract}

Objectives: To re-accomplish a survey of the affiliated organizations of the World Federation of Orthodontists (WFO) originally surveyed in 1997. Methods: An electronic survey was sent to all affiliated organizations of the WFO addressing specialty recognition, training, practice methods and characteristics of WFO affiliated organizations. Comparisons were made across geographic regions and not individual countries, in accordance with the previous survey. Results: The response rate was $68 \%$. Orthodontics is a well-recognized specialty with generally increasing educational, clinical and organizational standards worldwide. Board certification exists in relatively few countries, with the most commonly-cited reason being lack of demand. Emerging trends in clinical practice including temporary anchorage devices and cone beam computed tomography were widely-utilized. Conclusions: The 1997 survey was the first time a comprehensive evaluation of orthodontics throughout the world was evaluated, and the 2012 study represents the first comparisons to the 1997 data. 


\section{ACKNOWLEDGEMENTS}

I would like to thank the following for their significant contributions to this project:

Dr. H. Garland Hershey, for his guidance, patience and good humor.

Dr. Ceib Phillips, for her statistical insight.

Ms. Teresa Edwards, for her survey methodology expertise.

Dr. William DeKock, for his invaluable knowledge of WFO history. 


\section{TABLE OF CONTENTS}

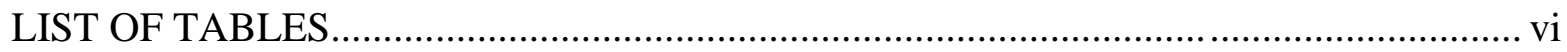

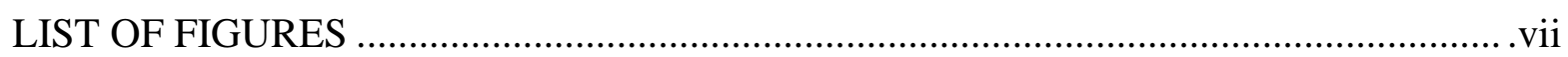

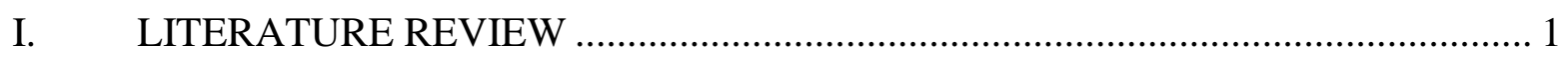

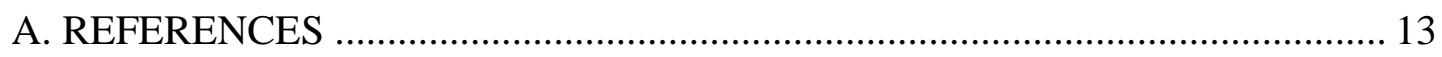

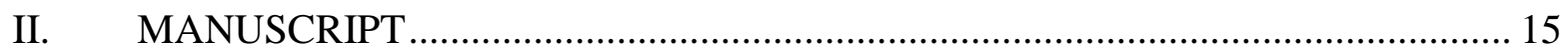

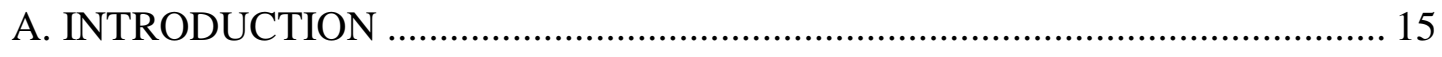

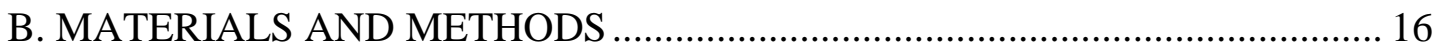

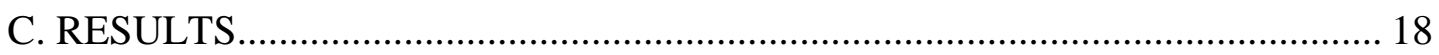

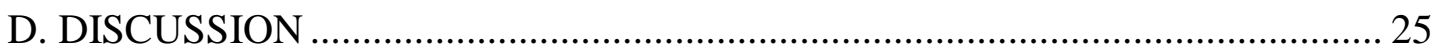

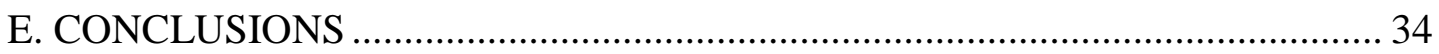

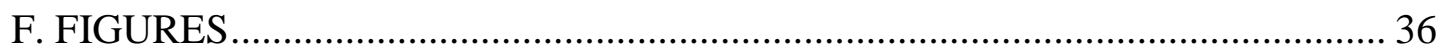

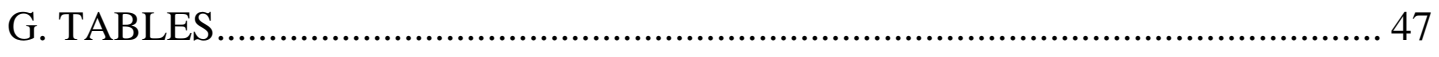

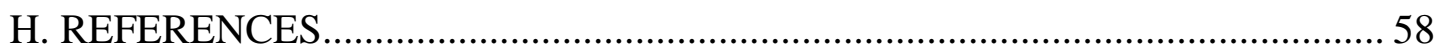




\section{LIST OF TABLES}

Table 1. Required Length of Postgraduate Orthodontic Programs to Fulfill Qualifications

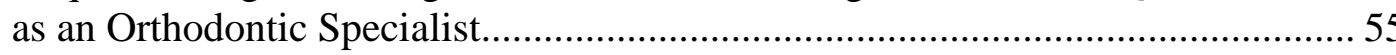

Table 2. Mean Percentage of Degrees and Certificates Awarded to Graduates of Orthodontic Programs.

Table 3. Percentage of Selected Options of Common Financial Arrangements for Orthodontic Training

Table 4. Percentage of Selected Options of Continuing Education Sources 57

Table 5. National Certifying Boards on WFO Board Committee (Year Founded and Percentage of National Organization Members Who are Board Certified

Table 6. Characteristics of Board Examination Process ...................................................... 59

Table 7. Mean Percentage of Who Orthodontists Practice With ............................................. 60

Table 8. Percentage of Selected Options of Orthodontic Treatment Financing Methods .... 60

Table 9. Percentage of Orthodontists' Use of Fixed Appliance Alone, Removable Appliance Alone, and a Combination of Fixed and Removable Appliances ........ 61

Table 10. Percentage of Prevalence of Temporary Anchorage Device Use ......................... 61

Table 11. Percentage of Prevalence of Lingual Fixed Orthodontic Appliance Use ............. 62

Table 12. Percentage of Prevalence of Clear Aligner Therapy Use .................................... 62

Table 13. Percentage of Prevalence of Laser Device Use ................................................... 63

Table 14. Percentage of Prevalence of Cone Beam Computed Tomography Use ............... 63

Table 15. The Ranking of Common Reasons for Temporary Anchorage Device Use......... 64

Table 16. The Ranking of Common Reasons for Cone Beam Computed Tomography ...... 65 


\section{LIST OF FIGURES}

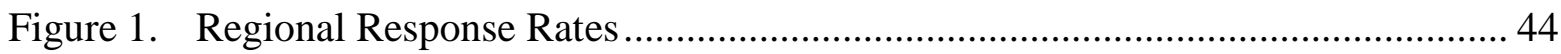

Figure 2. Percentage of Organizations in Regions with Government Recognition of Orthodontics as a Specialty

Figure 3. Percentage of Organizations in Countries Having a Written Definition for Orthodontics or Orthodontics and Dentofacial Orthopedics

Figure 4. Percentage of Organizations in Countries Requiring a Dental School Degree Prior to Orthodontic Training 46

Figure 5. Percentage of Organizations in Countries Requiring a Formal Postgraduate Orthodontic Program to Qualify as an Orthodontist.

Figure 6. Percentage of Private vs Public Dental Schools Per Region 47

Figure 7. Number and Quality of Orthodontic Programs Per Region

Figure 8. Percentage of Organizations in Countries with Accreditation Process for Dental Schools and Postgraduate Orthodontic Programs 48

Figure 9. Percentage of Organizations in Countries Requiring Periodic Continuing Education to Maintain Recognition as Orthodontist

Figure 10. Percentage of Organizations Without a Certifying Board in Their Country Who are Interested in How to Implement One.....

Figure 11. The Ratio of Orthodontists to General Dentists

Figure 12. The Average Percentage of Orthodontists Practicing in a Particular Region Who Were Trained in That Region.....

Figure 13. The Average Percentage of Orthodontists Trained in a Particular Region Who Continue Practicing in That Region.....

Figure 14. The Mean of the Percentage of Orthodontists Who Carry Malpractice Insurance

Figure 15. The Mean of the Percentage of Patients Treated with Comprehensive Orthodontics by an Orthodontist.

Figure 16. The Mean of the Percentage of Orthodontist-treated Patients Who are Adults (18 Years of Age or Older) 
Figure 17. The Mean Number of National Organization Members Per Region.

Figure 18. Percentage of Organizations Reporting There are Other Orthodontic Organizations in Their Country Not Affiliated with the WFO

Figure 19. Percentage of Organizations That Limit Their Membership to Orthodontic Specialists 53

Figure 20. Percentage of Organizations Publishing Their Own Orthodontic Journal.......... 54 


\section{LITERATURE REVIEW}

\section{The World Federation of Orthodontists: A Brief History}

\section{The Beginning}

The American Society of Orthodontists, later renamed the American Association of Orthodontists (AAO), was founded in 1900 and is the oldest dental specialty organization in the world. The orthodontic specialty flourished in the United States over the first half of the twentieth century as it pioneered many of the innovations leading to the modern fixed appliance, but orthodontics was developing in other parts of the world as well. This became evident during the first International Orthodontic Congress (IOC) held in New York in 1926, which was the first worldwide meeting held by any of the recognized dental specialties (1). Although another IOC was held in London five years later, it was not until 1973 that a third international meeting took place again in London. By this time, considerable influence from European advances in dentofacial orthopedics began to be felt in the United States through the popularization of functional appliances, and it was not uncommon for lectures given by internationally-trained orthodontists to be widely attended at the AAO Annual Session meetings.

By the 1990s, the AAO Annual Session had become the most attended orthodontic meeting in the world, owing in large part to a significant increase in the attendance of international AAO members. Because of this international involvement, there was considerable interest from the world orthodontic community to return to a more regularly scheduled international meeting, and in 1995 the fourth IOC was held in conjunction with the AAO Annual Session in San Francisco. 
Because of the increasing number of applications for international member status in the AAO, it became clear that it would be important to determine the educational background and organizational home of AAO international members, particularly since not all countries had formally recognized dental specialties. Members of the AAO leadership, in consultation with international colleagues, suggested that contacting the orthodontic specialty organization in each country would be the most effective way to confirm the credentials of international orthodontists wishing to join the AAO. After considerable investigation, they concluded that useful information on the existence or structure of the current orthodontic organizations or societies in countries around the world simply did not exist.

With the aid of the Federation Dentaire Internationale (FDI), the AAO leadership began to compile a list of international organizations representing orthodontic specialists worldwide. For those nations in which there were multiple competing societies, information from the FDI was used to identify the organizations in each country that best represented the most qualified orthodontic specialists. Using this list, invitations were extended to each so-identified organization to join in founding a new international orthodontic specialty organization, to be called the World Federation of Orthodontists (WFO). Among other important projected objectives, the WFO would serve to identify and represent orthodontic specialists around the world and be responsible for organizing an IOC every five years (2).

On May 15, 1995, sixty-eight organizations representing sixty-two countries became charter members of the WFO. This meeting was held at the Herbst Theatre in San Francisco, where fifty years earlier the United Nations Charter was signed by 
representatives of fifty countries (3). A small working group drafted and presented the WFO's bylaws, which described a proposed overall governing and leadership structure for the WFO. The bylaws identified the purpose of the WFO “...to advance the art and science of orthodontics throughout the world," a purpose guided by seven objectives designed to: encourage high standards of orthodontics throughout the world; encourage and assist in the formation of national associations and societies of orthodontists when requested; encourage and assist in the formation of national and regional certifying boards in the field of orthodontics when requested; promote orthodontic research; disseminate scientific information; promote desirable standards of training and certification for orthodontists; and organize the International Orthodontic Congress to be held at least once every five years (4).

The founding WFO leadership group focused their initial efforts on refining the leadership structure and further defining its criteria for membership, given the WFO's unique status as an organization comprised of both member societies and individual Fellows. The structure of the WFO was organized into the General Assembly (all WFO Fellows), the Council (comprised of one representative from each affiliate organization), and the Executive Council (the decision-making body of thirteen elected officials). The first Executive Council was initially the only operating branch. Dr. William H. DeKock was elected the first WFO president, and the elected WFO leadership devoted their early years to the cultivation of a global orthodontic community by identifying and recognizing individual orthodontic specialists, in some cases for the first time, in each affiliated organization's country. 
This objective of identifying and recognizing orthodontic specialists worldwide was met by crafting bylaws with explicit requirements that affiliated organizations must meet, perhaps the most important of which was a specified category of membership reserved exclusively for individuals meeting that country's requirements for recognition as an orthodontic specialist. It was required that if an orthodontic specialty accreditation agency or commission existed in that country, the affiliated organization must have that entity's endorsement for approved member status in the WFO (4). These stipulations for authenticity and quality were designed to enhance the WFO's credibility as an organization truly comprised of appropriately trained and credentialed international orthodontists.

After establishing well-defined requirements for its member societies, the WFO entrusted to the president of each affiliated organization the responsibility for approving the qualifications of every applicant for WFO Fellowship, further clarifying the objective that this was an organization exclusively for orthodontic specialists. Identifying these appropriately-trained providers of orthodontic care granted a level of recognition and distinction to the WFO Fellows not previously enjoyed in all countries. This served the WFO's clearly stated purpose of advancing the art and science of orthodontics around the world while also serving the AAO's desire to substantiate the qualifications of its international members. With such a system in place, the AAO stipulated that WFO Fellowship was a required prerequisite to AAO international membership.

\section{The 1997 Survey on the Status of Orthodontics Throughout the World}


The initial objective of identifying the orthodontic organizations and societies around the world proved to be difficult, and learning more about them was even more elusive, as no resource materials were available to provide global information on how orthodontics was taught, how it was practiced, or the demographics of who orthodontists in other countries were treating. Understanding this need, the WFO Executive Committee determined that a survey instrument was needed if the organization was to provide better data on the status of orthodontics throughout the world (5).

The product of these deliberations, the 1997 survey instrument, was a lengthy fourteen page document, with sixty questions contained in six sections: Regulations and Definitions; Legislation; Education; Human Resources; Orthodontic Practice Environment; and Characteristics of the WFO Affiliated Organization. The survey was distributed via international mail in 1997 to the presidents of the 81 WFO affiliated organizations. An impressive 85 percent response rate was achieved following a two-year collection period, which compares very favorably to recent response rates of AAO surveys that range between 18 to 39 percent (6-10).

Responses were not reported by each individual country, but were grouped into six geographically-related regions, which were Africa and the Middle East, Central and East Asia, Central and South America, Europe, North America, and South East Asia and Oceania. This approach simplified the organization and reporting of descriptive data, and reduced the potential for invidious comparisons among member nations while protecting the confidentiality of individual respondents.

The responses to the survey supplied the WFO with baseline information which for the first time provided descriptive data to characterize the world's orthodontic 
community. The survey results also created an appreciation and awareness of the differences and similarities of how the specialty is taught and practiced worldwide. If the purpose of the WFO was to indeed "advance the art and science of orthodontics throughout the world," an understanding of its current status was a necessary first step to achieve progress and harmonization (5).

\section{WFO Guidelines for Postgraduate Orthodontic Education}

The results of the survey not surprisingly demonstrated a wide range of orthodontic educational standards in place throughout the world. One early and beneficial outcome of the survey was that several of the respondents who were involved in their nation's education system solicited advice from the WFO on how their own training curriculum could be improved. Other more broadly applicable changes were generated as outcomes of the survey data, including a move to begin discussion at a 2001 Executive Committee Meeting to formulate universal education guidelines to aid countries in designing or improving their orthodontic training programs, and ultimately to provide standards that all programs could employ to guide their own development (11).

Further discussions of the survey results led to the creation of a special-focus committee formed to gather information from affiliated organizations, orthodontic program directors, and professional associations around the world to create broad educational guidelines that would directly serve the WFO's objective of promoting desirable standards of training. The chair of the committee, Dr. Donald Poulton of the United States, succinctly described the endeavor by stating that, "Education is basic to the improvement of orthodontics. It is also the basis of membership in the WFO" (12). 
Through the work of a number of committed individuals and after a number of drafts and revisions, the WFO Guidelines for Postgraduate Orthodontic Education were approved by the Executive Committee in 2003. The guidelines were designed to “...provide direction for universally recognized quality orthodontic specialty training" (13). While comprehensive in scope, the guidelines allowed flexibility depending on the available resources and potentially varied teaching methods of each organization. The guidelines also addressed a number of significant issue such as stipulating residents must possess a recognized dental school degree, program duration must be at least 24 months in length, desirable faculty and program director qualifications, clinical care and research facility recommendations, and curriculum outlines for clinical sciences, biomedical sciences, and original research. The educational guidelines were published in 2009 in the WFO's official journal, the World Journal of Orthodontics (14), and were also made available for use on the WFO's internet website.

\section{WFO Board Certification Guidelines}

Having created both a worldwide membership of specialty organizations and a valuable reference and standard for postgraduate orthodontic education, the WFO celebrated its ten-year anniversary in 2005 at the sixth IOC in Paris. In preparation for the meeting, the WFO began an attempt to clarify the role of orthodontic certifying boards by enlisting Dr. James Moss of England to head a committee investigating commonalities and differences among various certifying boards. To that end, the Moss Committee distributed a 22 question survey to $80 \mathrm{WFO}$ organizations that would be in attendance at 
the Paris IOC, with a primary focus to determine if each respondent's country had an orthodontic certifying board and, if so, its function (15).

This effort yielded 31 responses, the results of which were introduced to promote discussion at a forum held during the Paris meeting. Thirty representatives from nine international orthodontic certifying boards participated in the forum to offer suggestions on how the WFO could promote the growth and value of certifying boards (16). The results of the survey indicated that the majority of respondents (at least 24 of 31) felt that the existence of a certifying board demonstrated excellence, improved orthodontic standards, served as outside verification of standards independent of training programs, helped identify orthodontists of the same standard, and would reflect a higher level of professional competence. With regard to the content of the board examination itself, the vast majority agreed that the focus should be on the presentation and discussion of the candidate's own finished patient records. Not surprisingly, the recommended number of those case reports varied widely among the survey participants (16).

One of the committee's most interesting findings was the discovery of differing functions of certifying boards among countries. Two quite dissimilar approaches were evident, with a small group reporting that their board functioned primarily as a legal safeguard to protect the public, while the majority described their process as a voluntary professional peer assessment mechanism to demonstrate practitioner excellence. These two possible purposes of a certifying board were so fundamentally different that the possibility of implementing a universally accepted International Orthodontic Board was deemed by the committee to be unattainable. The majority of the forum attendees did 
agree that an affiliation of national and regional boards would be desirable, as sharing information would prove mutually beneficial to all participants (15).

The productive discussions in Paris were evidence of increasing worldwide interest in certifying boards, and in 2007 the WFO Committee on National and Regional Orthodontic Boards was established, chaired by Dr. Roberto Justus with the intent of creating an international affiliation of orthodontic certifying boards (17). Their initial approach was to collect the bylaws and examination criteria of as many boards as possible with the objective of disseminating their findings to generate discussion for improvements and to formulate guidelines for creating new certifying boards. The WFO Guidelines for the Establishment of New National and Regional Orthodontic Boards were approved by the Executive Committee in 2009 and identified the following four broad recommendations: similar to the ABO "Gateway Program," new orthodontists should be offered time-limited board certificates with subsequent required examination to maintain certification; all board-certified orthodontists should be recertified periodically to maintain a high level of care; board directors and examiners should serve a minimum of three years with staggered replacement to encourage new ideas while maintaining continuity; and all orthodontists who have completed their training within 36 months should be eligible to take the board exam and display five to ten clinical cases (18).

The output of the WFO Committee on National and Regional Orthodontic Boards culminated in a Symposium on Orthodontic Certifying Boards held at the seventh IOC in 2010 in Sydney. Over 100 orthodontists attended, including representatives from fifteen participating boards. The discussion included proposed refinements to the WFO board guidelines and featured important new topics such as the examination criteria of clinical 
cases, as well as the calibration method and recalibration interval of examiners (19). This marked the first time that a knowledgeable multinational group discussed the specifics of what constituted an effective board examination, and demonstrated a significant advance in creating an affiliation of orthodontic certifying boards the WFO had introduced as an objective five years earlier.

\section{A new baseline}

The strength of the World Federation of Orthodontists depends on an involved framework of member organizations consisting of competent, appropriatelytrained orthodontic specialists. This, in turn, is made possible through sound postgraduate training, career-long devotion to improving the quality of patient care, and enhanced by specialty board certification and recertification.

The 1997 survey on "The Status of Orthodontics Throughout the World” was conducted to understand how orthodontics was perceived as a profession, how it was practiced, and how orthodontists were educated and licensed. The 1997 data described the developmental level of the profession in each country, enabling the WFO to better understand the needs of its affiliated organizations. In response, the WFO amended bylaws, putting in place a mechanism of educational emphasis to ensure that its member organizations and Fellows represented only appropriately qualified orthodontic providers. Later, the WFO produced the first postgraduate orthodontic education guidelines representing a consensus on quality training. And most recently, the WFO created the first affiliation of orthodontic certifying boards for the mutual benefit of the affiliates, as well as to inform countries and societies interested in creating new certifying boards. 
The WFO's impressive contributions to the world orthodontic community were, in part, informed by the input received by respondents of the 1997 survey. The stage for an updated survey was set in 2000 when as he left the WFO presidency, Dr. William DeKock expressed hope that the WFO would continue to collect data on the status of orthodontics throughout the world, envisioning that the WFO could become "a repository from which national organizations can obtain information" (20). More than a decade after first reporting the results of the 1997 survey, a new baseline on the status of orthodontics throughout the world is clearly indicated. 


\section{References}

1. Graber LW. The world federation of orthodontists: Work in progress. Prog Orthod. 2005;6(2):136-139.

2. Curtis, E. Orthodontics at 2000. $1^{\text {st }}$ ed. St. Louis: American Association of Orthodontists; 2000.

3. DeKock WH, Graber LW. The World Federation of Orthodontists: "Bringing the World Together". Am J Orthod Dentofacial Orthop. 2000;117(5):536-537.

4. World Federation of Orthodontists. "Bylaws of the World Federation of Orthodontists.” World Federation of Orthodontists. 4 Feb. 2010 $<$ http://www.wfo.org/Bylaws.aspx >

5. DeKock WH. A WFO-commissioned study provides data on the specialty's current characteristics and standards. WFO Gazette. 2000;5(2):1.

6. Bedair TM, Thompson S, Gupta C, Beck FM, Firestone AR. Orthodontists' opinions of factors affecting patients' choice of orthodontic practices. Am J Orthod Dentofacial Orthop. 2010;138(1):6.e1-7; discussion 6-7.

7. Brown BR, Inglehart MR. Orthodontic care for underserved patients: Professional attitudes and behavior of orthodontic residents and orthodontists. Angle Orthod. 2011;81(6):1090-1096.

8. Burke B, Hamdan AM, Tufekci E, Shroff B, Best AM, Lindauer SJ. Perceptions of soft tissue laser use in orthodontics. Angle Orthod. 2012;82(1):75-83.

9. Madhavji A, Araujo EA, Kim KB, Buschang PH. Attitudes, awareness, and barriers toward evidence-based practice in orthodontics. Am J Orthod Dentofacial Orthop. 2011;140(3):309-16.e2. 
10. Pratt MC, Kluemper GT, Hartsfield JK,Jr, Fardo D, Nash DA. Evaluation of retention protocols among members of the american association of orthodontists in the united states. Am J Orthod Dentofacial Orthop. 2011;140(4):520-526.

11. Kassel J, editor. WFO Executive Committee convened in Toronto during $101^{\text {st }}$ AAO Annual Session. WFO Gazette. 2001;6(1):1.

12. Kassel J, editor. WFO Executive Committee held a teleconference in November. WFO Gazette. 2001;6(2):1

13. Kassel J, editor. WFO Executive Committee approves Orthodontic Specialty Education Guidelines to assist academic institutions. WFO Gazette. 2003;8(2):1.

14. Athanasiou AE, Darendeliler MA, Eliades T, et al. World federation of orthodontists (WFO) guidelines for postgraduate orthodontic education. World J Orthod. 2009;10(2):153-166.

15. Moss JP. Results of the questionnaire on orthodontic boards. Prog Orthod. 2006;7(1):16-23.

16. Kassel J, editor. Representatives from national orthodontic certification boards share information, offer suggestions as to how the WFO could assist boards. WFO Gazette. 2005;10(2):6.

17. Kassel J, editor. WFO Executive Committee expands its committee on national, regional orthodontic certifying boards. WFO Gazette. 2007;12(1):1.

18. Kassel J, editor. Guidelines to aid in setting up national, regional certifying boards. WFO Gazette. 2009;14(1):1.

19. Kassel J, editor. Symposium on Orthodontic Certifying Boards ignites interest in board certification among WFO affiliate organizations. WFO Gazette. 2010;15(1):1. 
20. Kassel J, editor. Dr. William DeKock, immediate past president of the WFO, takes on new role as secretary-general. WFO Gazette. 2000;5(1):4. 


\section{MANUSCRIPT}

\section{INTRODUCTION}

The World Federation of Orthodontists (WFO) was founded in 1995 as a mechanism for the American Association of Orthodontists (AAO) to confirm the credentials of prospective AAO international membership applicants (1). By 1997, the WFO had grown into a global orthodontic community with eighty-one affiliated organizations representing over seventy countries. No resource was available, however, to characterize these organizations or to understand the development of the profession in each country. In an effort to comprehend how orthodontics was perceived as a specialty, and to determine how it was taught and practiced in each member nation, the WFO developed a survey instrument to help them describe the status of orthodontics worldwide (2).

The results of the survey provided the WFO with useful data to formulate a strategy for fulfilling its stated mission to "...advance the art and science of orthodontics throughout the world." The WFO began to implement this mission through an extensive joint effort with its member organizations to recognize orthodontic specialists worldwide as the most appropriately-trained providers of orthodontic care, thereby bestowing a level of distinction not previously enjoyed in all countries (1). The next several years produced 
many initiatives to advance the specialty, which included the WFO Guidelines for Postgraduate Orthodontic Education (3) and the WFO Guidelines for the Establishment of New National and Regional Orthodontic Boards (4).These guidelines presented for the first time a collection of widely-accepted, desirable elements of effective orthodontic training and board examinations, providing prototypes for organizations wishing to initiate or enhance orthodontic programs or certifying boards.

These important WFO contributions to the world orthodontic community were, in part, guided by the results of the 1997 survey. Since that investigation, twenty-eight affiliated organizations have joined the WFO, and the landscape of orthodontics has changed dramatically, with more countries contributing to the development of orthodontic research and knowledge each year. If the WFO is to continue to better understand its member organization needs and be of further service to the profession, updating and building upon the information obtained from the 1997 survey is necessary.

\section{MATERIALS AND METHODS}

\section{The survey instrument}

The 2012 survey instrument was designed to provide data that would update, expand, and enable meaningful comparisons with the data from the 1997 survey. The study was organized into five sections that were similar to the structure of the 1997 survey:

- Regulations and Legislation

- Education 
- Human Resources

- Orthodontic Practice Environment

- Characteristics of Your WFO Affiliated Organization

The individual questions were designed to be closed-ended and forced-choice with an option to provide elaboration if the respondent felt it was necessary.

\section{Survey participants and procedures}

The WFO is comprised of 109 affiliated organizations, although, nine of them are regional organizations representing multiple societies and countries. Because the scope of this investigation was to understand organizational characteristics specific to each nation, the regional organizations were excluded. The presidents of the remaining 100 affiliated national organizations were the recipients of the survey. Email addresses of the affiliates' presidents were obtained from the WFO, and a message was sent explaining the purpose of the study and asking them to complete the online survey (Qualtrics Labs, Inc., Provo, UT). The recipients were informed their responses would not be reported individually or by country, but rather by geographic regions. This was done in an effort to encourage accurate responses and protect the confidentiality of the respondents. Due to the length of the survey, two reminder emails were sent one month apart for a total of three electronic contacts. Upon closing the online survey, non-respondents and potential participants without email addresses were sent a paper version of the survey (Cardiff TeleForm, Vista, CA) via one international postage contact.

\section{Data collection}


Data from the Qualtrics and TeleForm versions of the survey were merged, and descriptive statistics were produced (SAS version 9.2, Cary, NC). Results were grouped into six geographically-related regions that had been designated by the 1997 project:

- Africa and the Middle East

- Central and East Asia

- Central and South America

- Europe

- North America

- Southeast Asia and Oceania

\section{RESULTS}

\section{Response rate}

Data collection began May 1, 2012 and ended Dec 1, 2012. 53 electronic surveys and 15 paper surveys were completed for a total of 68 responses and an overall 68 percent response rate. This was a decrease from the 85 percent response rate achieved in 1997, with 69 of 81 affiliated organizations completing the survey. Although regional response rates were not reported in the previous study, the current results indicated at least a 65 percent response rate was achieved in each region, with the exception of Africa and the Middle East (37 percent) (Figure 1).

\section{Regulations and Legislation}


Orthodontics demonstrated high recognition as a specialty, with 94 percent of WFO member organizations having reported general public recognition of the specialty in their country. Official government recognition of the specialty was more varied among regions, although a general increase was seen since 1997 (Figure 2). Countries having a written definition for orthodontics or orthodontics and dentofacial orthopedics also varied among regions, which is consistent with the previous study's findings (Figure 3).

With regard to educational and training qualifications, the 2012 results demonstrated that virtually all regions' orthodontists required a dental degree prior to specialization training, which represented a substantial change from 1997 (Figure 4). Dental programs throughout the world had average lengths of at least five years in both studies with the exception of North America, which reported average lengths of four years in both investigations. The number of countries requiring a formal university or hospital-based postgraduate program in orthodontics for specialist recognition also increased overall, particularly in Europe (Figure 5). The nationally mandated length of these educational programs in each region remained similar, with Europe having the longest mean program length and Central and South America having the lowest in both reports (Table 1). Preceptorship training remained an acceptable form of orthodontic education in some regions, although the numbers have decreased from nine countries in 1997 to four countries in 2012.

\section{Education}

The number of dental schools in member nations increased in five of the six regions, increasing the number of dental providers. In particular, substantial growth in the 
number of dental schools was observed in Central and East Asia and Central and South America (Figure 6). The percentage of private institutions increased in all but one region, and for most regions there were more private dental schools than public. Moreover, only two regions in both 1997 and 2012 (Africa and the Middle East and Europe) had a higher percentage of public schools than private. Respondents were asked to indicate the number of postgraduate orthodontic programs in their countries that they believed to be of an acceptable standard and below an acceptable standard. While the total number of orthodontic programs increased in four of the six regions, only two regions experienced a decrease in the number of programs believed by the respondents to be below acceptable standard programs, with Central and South America having increased to 241 below acceptable standard programs, by far the largest number reported in either study (Figure 7).

Table 2 depicts the degrees and certificates granted by orthodontic programs, and across regions, a certificate of completion currently represents the most commonly offered documentation of training, while the Master's degree appeared more prevalent in 1997 (Table 2). In both years, however, the $\mathrm{PhD}$ was the least offered type of degree.

Accreditation processes for dental school and postgraduate orthodontic programs increased or remained at 100 percent in four regions (Figure 8). While the 1997 data did not specify accreditation processes exclusively for orthodontic programs, the 2012 results indicated that overall across regions 93 percent of organizations reported such an accrediting mechanism existed for orthodontic training in their country. 
Regarding the financial arrangements during orthodontic training, tuition payment remained the most prevalent. Although not as common, the percentage of orthodontic students receiving stipends, as well as the percentage practicing part-time while training increased in four regions (Table 3).

Continuing education (CE) to maintain recognition as an orthodontist was not investigated in 1997, but 2012 results indicated that three of six regions had 50 percent or fewer organizations reporting that continuing professional education was required (Figure 9). Regardless of requirement, the most common method of earning CE credit was attendance at programs delivered at an orthodontic specialty meeting (Table 4). This was followed by reading orthodontic journals, while internet courses and study clubs represented the least common mechanism of earning CE hours.

Although orthodontic board certification was not addressed in the 1997 survey, in 2012 there were 14 national boards participating in the WFO Committee on National and Regional Orthodontic Certifying Boards. Of these entities, only three were founded prior to 1993, with the American Board of Orthodontics representing the oldest with a founding year of 1929 (Table 5). Regarding certification rate, the percentage of national organization members who are board certified was 30 percent or less in 13 of the 14 certifying boards. The content of these examinations typically consisted of evaluating records of patients the candidate had treated, often combining this method with a written examination (Table 6). Evaluation of patient records the candidate had not seen before was the least-featured method of assessing competency. Respondents who did not have a certifying board in their country were asked if they were interested in information on how to implement a board certification process. Figure 10 demonstrated that only Southeast 
Asia and Oceania expressed no interest, while the remaining regions had nearly half their constituent organizations interested in pursuing the development a certifying board in their country (Figure 10).

\section{Human Resources}

Direct comparison of the ratio of orthodontists to general dentists (non-specialists) was not possible between the two surveys, but in 2012 Europe exhibited the fewest orthodontists relative to dentists with 317 non-specialists per orthodontist. Central and South America had the highest relative number of orthodontists with nine general dentists per orthodontist (Figure 11).

Figures 12 exhibited a general trend of increasing percentages (four of six regions) of orthodontists within a region who were also trained in that region (Figure 12). These same four regions also demonstrated a dwindling percentage of orthodontists training in a particular region and then staying there to practice (Figure 13). This means that there was an increasing segment of orthodontists in a given region who were trained in that region, while interestingly the percentage of orthodontists willing to leave the country they were trained had also increased.

\section{Orthodontic Practice Environment}

In all regions the most common practice model was that of solo practice or with other orthodontists, as opposed to practicing with general dentists or other nonorthodontist specialists (Table 7). 
With respect to malpractice coverage, all but one region experienced an increased percentage of orthodontists carrying malpractice insurance, although no region had 100 percent of its orthodontists holding such a policy (Figure 14).

Although the prevalence of various orthodontic treatment financing schemes differed greatly from region to region, full complete payment from either the patient or the patient's family represented the most-reported mechanism in both 1997 and 2013 (Table 8). Of all the options, complete insurance financing was least common in both studies, while payment with combined insurance and patient or parent funds was more common, particularly in North America. Government financing, either by itself or with patient or family contributions, was most appreciable in Africa and the Middle East and Europe.

The percentage of orthodontic patients treated by an orthodontic specialist increased in all six regions (Figure 15), with large increases observed in both Central and East Asia (from 33 percent to 62 percent) and Southeast Asia and Oceania (40 percent to 76 percent). Of these patients treated by orthodontists, the percentage of those who are adults had risen in all but one region, with North America decreasing by half (Figure 16).

Respondents were asked to estimate the percentage of cases treated with a fixed appliance alone, a removable appliance alone, or a combination of a fixed and removable appliance. Of these choices, the percentage of cases treated with a fixed appliance alone was the highest, not only in all regions, but in both studies (Table 9). The use of a removable appliance alone for treatment decreased in four regions with only a modest increase in the other two. Of particular interest is the large decrease noted in Europe (40 
percent to 17 percent), although it still represented the region using the highest percentage of a removable appliance alone. The combined treatment approach of a fixed and removable appliance increased in all but one region.

Tables 10 through 14 represent estimates of the 2012 prevalence of technology either not available or rarely-used in 1997. Temporary anchorage devices (TADS) (to include miniscrew implants and bone miniplates) were the most frequently utilized emerging technology (Table 10), and while not quite as prevalent, both clear aligner therapy (Table 12) and cone beam computed tomography (CBCT) (Table 14) were widely-used. Lingual orthodontic appliances (Table 11) and laser devices (Table 13) were the least utilized.

TADs are versatile adjuncts to orthodontic care, and respondents were asked to rank four typical reasons for using them. With only one exception, all regions considered space closure anchorage to be the most common reason to employ TADs (Table 15), while use as an aid in Class II malocclusion correction followed. Although use for Class III growth modification was identified as the least common reason for placing TADs overall, Southeast Asia and Oceania selected it as the most common reason.

Similar to TADs, CBCT is prescribed for many distinctly different purposes, even if it is simply a radiographic imaging tool. The location of impacted teeth ranked as the most common reason for CBCT, with orthognathic surgery planning coming in second (Table 16). Examining patient airway appeared slightly more popular than using CBCT for routine orthodontic treatment planning, but cone beam imaging for the fabrication of custom brackets and wires was clearly the least common reason selected. 


\section{Characteristics of WFO Affiliated Organizations}

National organization membership increased in four of six regions and remained virtually the same in North America (Figure 17), with only Central and East Asia having demonstrated a drop in participation.

With regard to orthodontic organizations not affiliated with the WFO, Central and South America experienced a three-fold increase in reports of such societies (Figure 18). Of those organizations that are WFO affiliates, Africa and the Middle East, Central and South America, and North America had the highest percentage that limit their membership exclusively to orthodontic specialists (Figure 19).

The percentage of organizations publishing their own orthodontic journal decreased in four regions, and currently no region has more than half of its organizations with their own research publication (Figure 20).

\section{DISCUSSION}

The 2012 survey was only the second time a comprehensive examination of the international orthodontic environment had been conducted, but the manageable 100 recipients aided in creating a cost-effective method of obtaining information describing a profession serving large populations. The presidents of national organizations were selected to represent an entire country of orthodontists because surveying the orthodontists in each nation was simply not realistic given the lack of adequate contact information in many of the member nations. Although not ideal, it was felt the presidents 
of the national organizations would, in most cases, be in the best position to access reliable resources informing accurate responses. Nevertheless, determining the validity of the information provided is impossible, with language barriers further complicating the matter. Although all WFO organization presidents were assumed to have some familiarity with the English language, misinterpretation of the survey questions was clearly a possibility. Future studies could consider translation of the survey into at least a few different languages in an effort to increase response accuracy.

While the 1997 survey's 85 percent response rate was quite remarkable (particularly since electronic survey distribution was not prevalent then), the 2012 response rate of 68 percent still compared very favorably to recent AAO surveys which ranged from 18 to 39 percent (5-9). In light of the fact this survey was distributed to dozens of different countries speaking multiple languages, this participation rate is perhaps even more impressive. While the 1997 investigation allowed two years to collect data, the 2012 survey closed after seven months. The two year data collection timeframe in 1997 allowed president turnover, perhaps to someone more conversant with English. It also enhanced the ability to arrange personal reminders about completing the survey at the AAO Annual Session and other international meetings.

\section{Regulations and Legislation}

The disparity between the high general recognition of orthodontics as a specialty by the public and the lower recognition by government entities is likely explained by the stricter mandates required by governing health bodies officially empowering the specialty to assess its own standards. In some countries, general dentists with no formal 
postgraduate training beyond their own focused interest in orthodontics, may legally be able to declare themselves orthodontists with the public assuming that special skills are associated with that self-designation. By contrast, other countries require a formal postgraduate education in orthodontics to legally declare one's practice limited to orthodontics.

Having a written definition for orthodontics or orthodontics and dentofacial orthopedics was not rare, yet only two regions had more than two-thirds of their organizations reporting that such a definition existed. While it is possible these countries were simply unofficially subscribing to the definition proposed by another country or organization, having one suggests an overall vision or set of goals for the specialty and what it hopes to accomplish for its patients.

While virtually all organizations reported that a dental school degree was required before specializing in orthodontics, this was not the case in 1997. The particularly low percentage observed in Europe in 1997 (12 percent) was especially difficult to explain. While both surveys used generic terms and did not specify a degree type (e.g., D.D.S. or D.M.D.), it is possible some respondents were confused because in many countries university study and dental training are one and the same, and a separate college degree is often not required before dental training begins.

With regard to postgraduate orthodontic education, the number of countries requiring this training increased, while two regions exhibited small declines. It is interesting to note that of these two regions there were twice the number of responses from Central and East Asia and one fewer response in Southeast Asia and Oceania (a 
region with only six countries) in the new study. The longest minimum required program length was observed in Europe, most likely the outcome of the European Action Scheme for Mobility of University Students (ERASMUS) Program developed to allow mobility of orthodontists throughout the European Union. Such an initiative would, of course, require standardized guidelines for training, with one of these guidelines stipulating an orthodontic program length of at least three years (10). Central and South America reported programs of one year or less fulfilling sufficient requirements for orthodontic training, and this region also had the lowest mean minimum program length. More on this region's educational standards will be discussed below.

\section{Education}

Both the number and percentage of dental schools that are private institutions increased, and while not all orthodontic programs are located in dental schools, this increase in private institutions may explain the general increase in orthodontic students paying tuition observed in Table 3. While the number of postgraduate orthodontic programs was higher across most regions, the proportion of them characterized as below an acceptable standard is alarming, particularly in Central and South America. Because Brazil has described problems with general dentists declaring themselves orthodontists (11), it is possible many of these programs were short "weekend courses" for dentists to be introduced to basic techniques for the initiation of uncomplicated orthodontic treatment. Nevertheless, approaching the governing body responsible for dental health care in these countries should be of considerable interest to the national organizations reporting programs considered below an acceptable standard, and if requested, the WFO could be a very positive resource to use data from this project, as well as the WFO 
Guidelines for Postgraduate Orthodontic Education (3) to demonstrate the current world standard in orthodontic training.

The process of formal accreditation for dental schools and orthodontic programs is an important component to ensure educational standards are met. The decrease in percentage of these mechanisms observed in Africa and the Middle East may have been the result of one less response in 2012; likewise, the European region has grown considerably since the 1997 survey, and whether accreditation is becoming less utilized or if the 2012 data simply provides a wider and thus more accurate capture of the region is not possible to determine.

In looking at the types of degrees offered by orthodontic training programs, the increase in certificates of completion may suggest more student interest in programs that are either shorter in length or have reduced research requirements. Future studies could clarify the differences in curricula among programs offering certificates of completion versus programs granting Master's of Doctorate degrees. The relatively low prevalence of $\mathrm{PhD}$ degrees is likely explained by the longer time commitment, its limited utility in a patient care setting and the low percentage of orthodontists employed in an academic capacity.

While not investigated in 1997, required continuing education was reported to be uncommon in both Central and East Asia and Central and South America, which does not necessarily imply that continuing education was not a priority for providers in those regions. While it is not surprising that $\mathrm{CE}$ obtained at professional meetings or from professional journals was common, it will be interesting to see if internet courses become 
more prevalent in the future, particularly with the rising popularity and proven effectiveness of distance learning materials (12).

The low percentage of national organization members who are board certified suggests substantially lower numbers when compared to the board certification rate of all orthodontists in a country. Establishing a board certification process is a complex undertaking. For example, although the Brazilian Board of Orthodontics was established in 2000, its first examination was not conducted until 2004. Substantial time and effort is necessary to establish a board of directors, formulate bylaws and the particulars of the examination process, enlist qualified examiners who require training and calibration, and then generate interest and a commitment from orthodontists in that country to subject themselves to the examination. It is perhaps not surprising that the board certification rates were quite low given that the majority of the boards were not established until the 1990s and later.

With respect to the certification process itself, it makes sense that most of the examinations focus on the quality of the candidate's finished cases since the mission of most boards is to assess clinical competence and professional excellence. The common use of a written examination reflects the importance of demonstrating a sound didactic background for the clinical decisions candidates make, and although evaluating a case the candidate has not seen before is not frequently reported, it supports the evaluation of critical thinking skills.

Those organizations that do not have board certification in their country but would like more information on how to implement one should be of particular interest to 
the WFO. If the WFO wishes to support the growth of board certification worldwide, providing assistance to these organizations in the form of the WFO Guidelines for the Establishment of New National and Regional Orthodontic Boards (4) will be necessary.

\section{Human Resources}

When asking respondents to innumerate the number of dentists in their country, the 1997 survey did not specify the interest was in general dentists (non-specialists), and respondents may have been including orthodontists and other specialists in the total. Therefore, obtaining a ratio of orthodontists to general dentists was not possible for comparison. In 2012, however, it's interesting to note that the smallest ratio of orthodontists to general dentists was observed in Central and South America, which also boasts a large number of orthodontic programs. Europe, however, also has many orthodontic programs but has by far the largest number of general dentists to orthodontists. This is likely explained by Europe's substantially higher number of countries relative to Central and South America. More difficult to understand, however, is that Central and East Asia has more orthodontic programs spread among fewer countries than Central and South America, yet it still has a higher ratio of orthodontists to general dentists, presumably due to more dental schools graduating higher numbers of dentists. Alternatively, the orthodontic programs in Central and East Asia may be graduating fewer students per class than those in Central and South America.

\section{Orthodontic Practice Environment}

The percentage of comprehensive orthodontics performed by orthodontic specialists has increased in all regions, implying that orthodontists are enjoying higher 
recognition of their special skills, despite the increased visibility of appliances and treatment approaches aimed at making orthodontics more accessible to general dentists. The percentage of adult patients treated by orthodontists also increased in all regions except North America, and although there are three countries within this region, the trend of a decreasing percentage of adult patients is consistent with recent reports in the United States (13).

The current study demonstrated a general decrease in orthodontists' use of a removable appliance alone. Europe, which accounted for the highest such use, also had the largest decrease from 41 percent to only 17 percent. This seems to indicate a changing climate in the region known for its ubiquitous use of removable appliances for tooth movement and growth modification. Still, Europe had a high rate of using a combination of both fixed and removable appliances, implying it is not completely abandoning removable devices. By contrast, in both studies North America and Southeast Asia and Oceania exhibited the lowest use of a removable appliance alone and the highest percentage of using only a fixed appliance for treatment needs, perhaps suggesting a general disfavor in these regions of treatment modalities requiring patient compliance.

If the contents of recent orthodontic journals are any indication, the widespread use of TADs and CBCT should come as no surprise. And while clear aligner therapy is still valuable to orthodontists throughout the world, it seems to represent simply another way of moving teeth, as opposed to the enhancements that TADs and CBCT provide. Although there have been recent improvements in lingual appliance design and clinical techniques, these appliances have long been regarded as difficult for both patient and operator, while the relatively low prevalence of laser devices may be accounted for by 
orthodontists' general aversion to encroaching on what is perceived as the periodontist's area of expertise.

Regarding the ranked reasons of why providers use TADs, anchorage for space closure represents the most commonly-cited reason perhaps because it's the most straightforward application to biomechanics as well as an easily-grasped solution to a very frequently-encountered clinical problem. Future studies may demonstrate, however, that TADs in service of growth modification may rise significantly as more research explores this function of skeletal anchorage.

The survey data indicate the use of CBCT to locate impacted teeth is the clear consensus on 3D imaging's most common use in orthodontics, likely because information obtained from CBCT for this purpose so greatly benefits the orthodontist, oral surgeon and patient. CBCT was also commonly employed for the planning of orthognathic surgery, possibly because of emerging technology for computer-assisted fabrication of surgical splints and fixation plates. Related to orthognathic surgery, CBCT airway evaluation is likely to become more important as awareness of sleep apnea and its relation to surgical jaw movements increases. Many practitioners evidently regard the use of $\mathrm{CBCT}$ for routine orthodontic treatment planning as a less compelling reason for prescribing a scan, possibly because of increasing public attention to the judicious use of radiation and a higher premium being placed on risk and benefit analysis of such imaging. Similarly, because photographic scans are sufficient for many of the computermade custom brackets and wires and because of their relatively low use among orthodontists, few respondents considered CBCT for the fabrication of custom brackets and wires to be of great importance. 


\section{Characteristics of WFO Affiliated Organizations}

While the mean number of national organization members increased in four regions, the only substantial rise was observed in Central and South America. The more modest increases, as well as the decrease observed in two regions, could be the result of more organizations joining the WFO since 1997 that have a small membership, or because fewer numbers of new orthodontists join professional societies. The WFO should take note of the existence of unaffiliated orthodontic societies. Although these organizations may not currently have the governing body and bylaws necessary to meet current WFO standards, some may be valuable additions to the world orthodontic community.

\section{CONCLUSIONS}

The 1997 WFO survey was unique, and represented the first comprehensive study of the status of orthodontics worldwide. The current investigation demonstrates for the first time changes that have occurred since 1997, and provide data that future studies can build upon to continue to advance the art and science of orthodontics throughout the world. Examination of the data from the 2012 WFO Survey of Orthodontics Worldwide warrants the following conclusions:

- Orthodontics is enjoying a higher level of recognition worldwide.

- In general, orthodontic education standards appear to be increasing.

- The number of dental schools and orthodontic programs has grown in most regions, producing an increase in fully trained orthodontic providers. 
- Although the proportion of national orthodontic certifying boards to countries is low, and board certification rates are also low, it is possible that these numbers will increase in that the majority of these boards are relatively young and need time and assistance to mature and build value.

- The landscape of how orthodontics is delivered has changed dramatically due to the introduction of new technology. 


\section{FIGURES}

Figure 1. Regional Response Rates

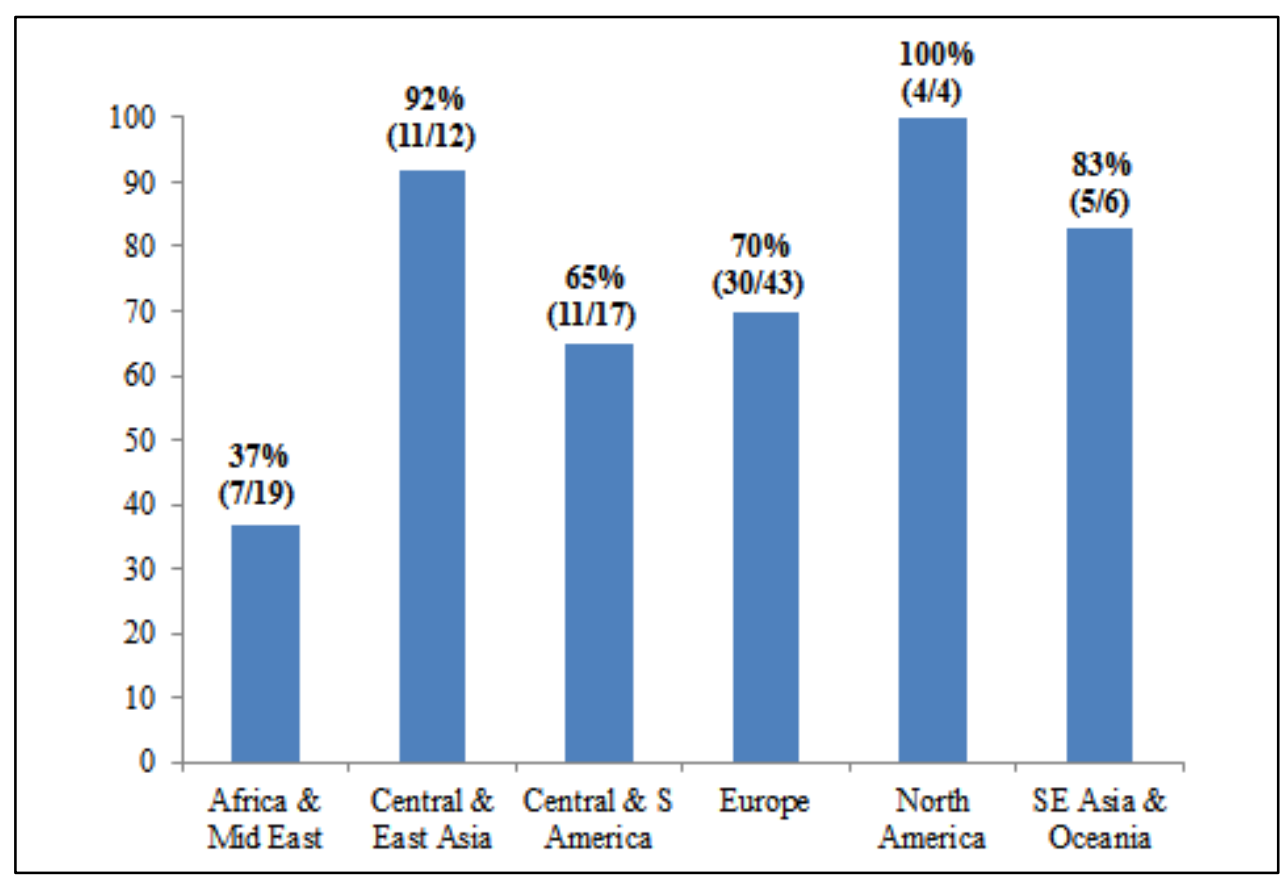


Figure 2. Percentage of Organizations in Countries with Government Recognition of

Orthodontics as a Specialty

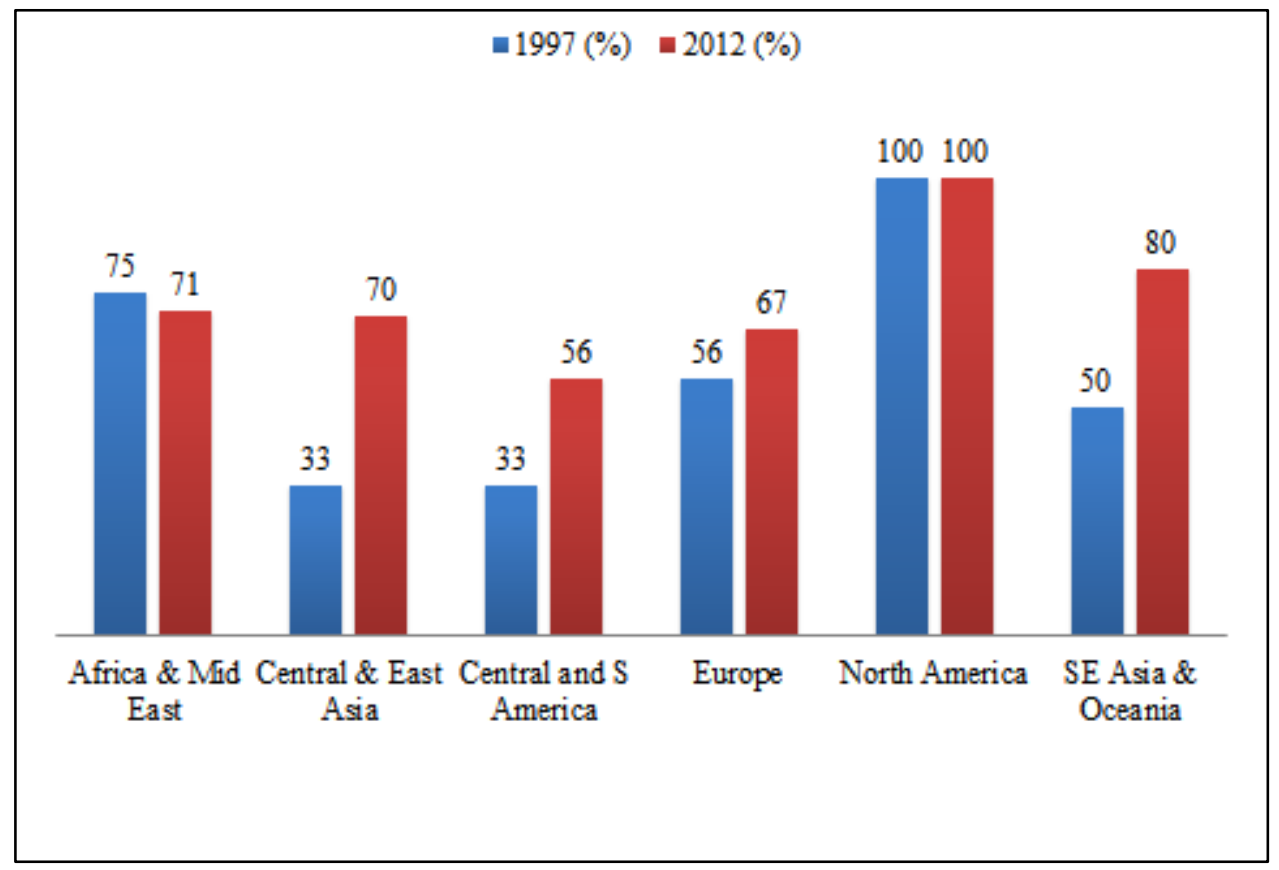

Figure 3. Percentage of Organizations in Countries Having a Written Definition for

\section{Orthodontics or Orthodontics and Dentofacial Orthopedics}

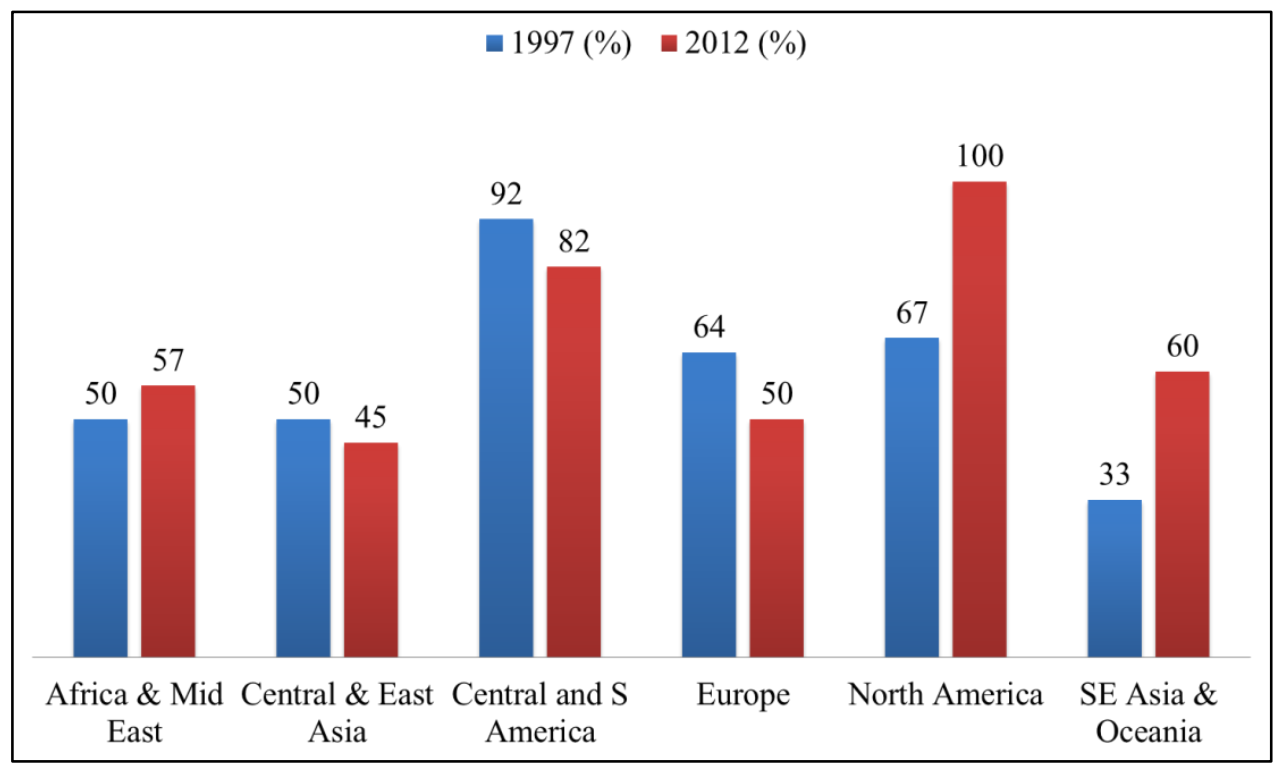


Figure 4. Percentage of Organizations in Countries Requiring a Dental School

\section{Degree Prior to Orthodontic Training}

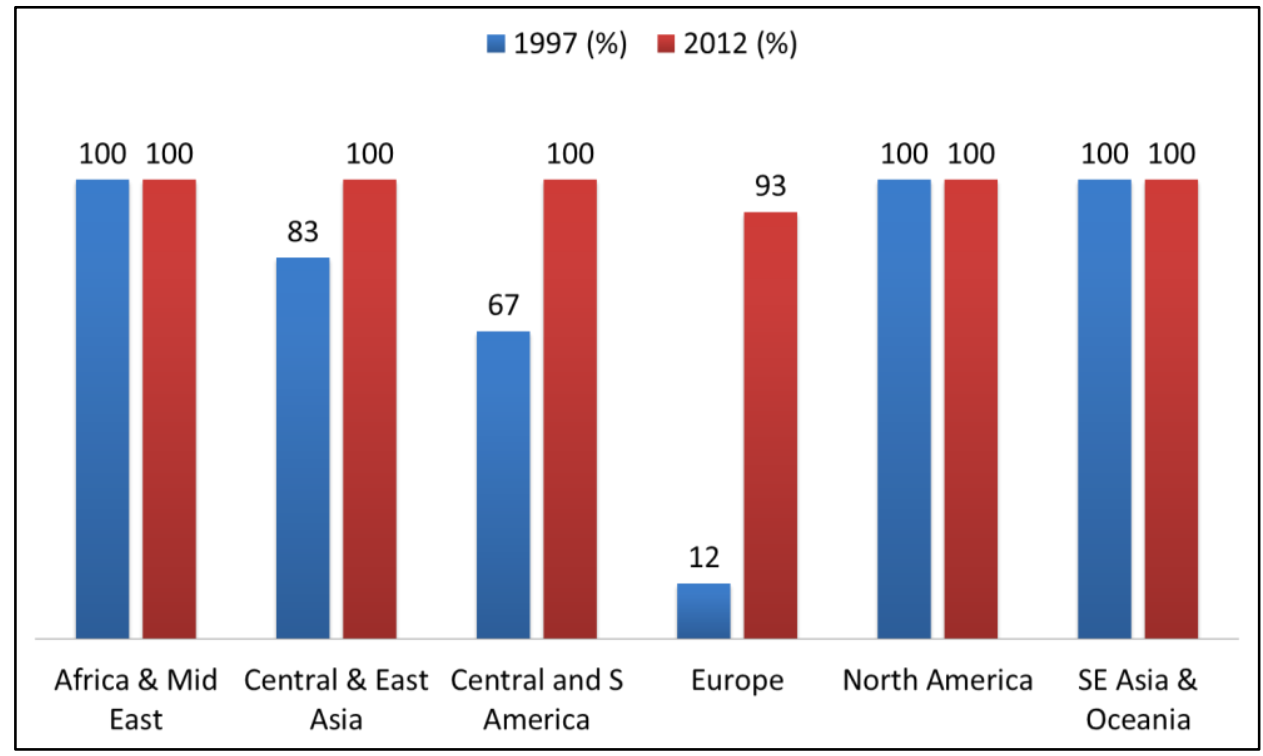

Figure 5. Percentage of Organizations in Countries Requiring a Formal

\section{Postgraduate Orthodontic Program to Qualify as an Orthodontist}

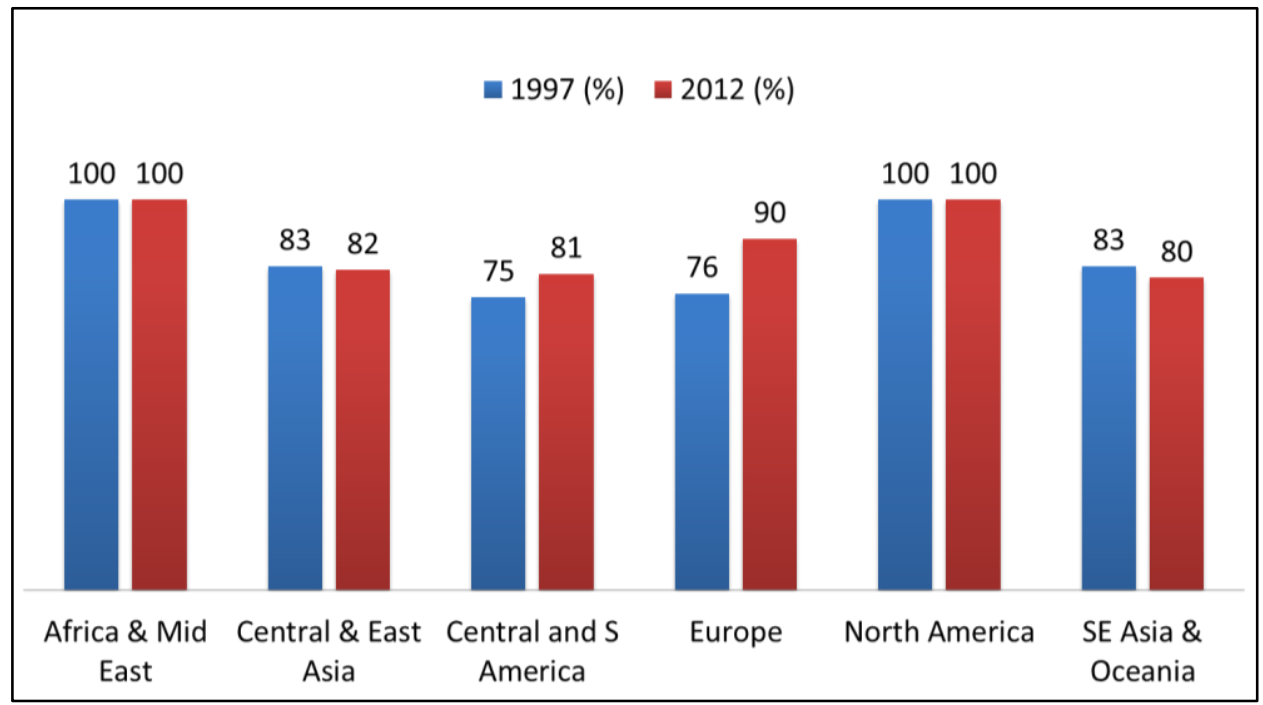


Figure 6. Percentage of Private vs Public Dental Schools Per Region

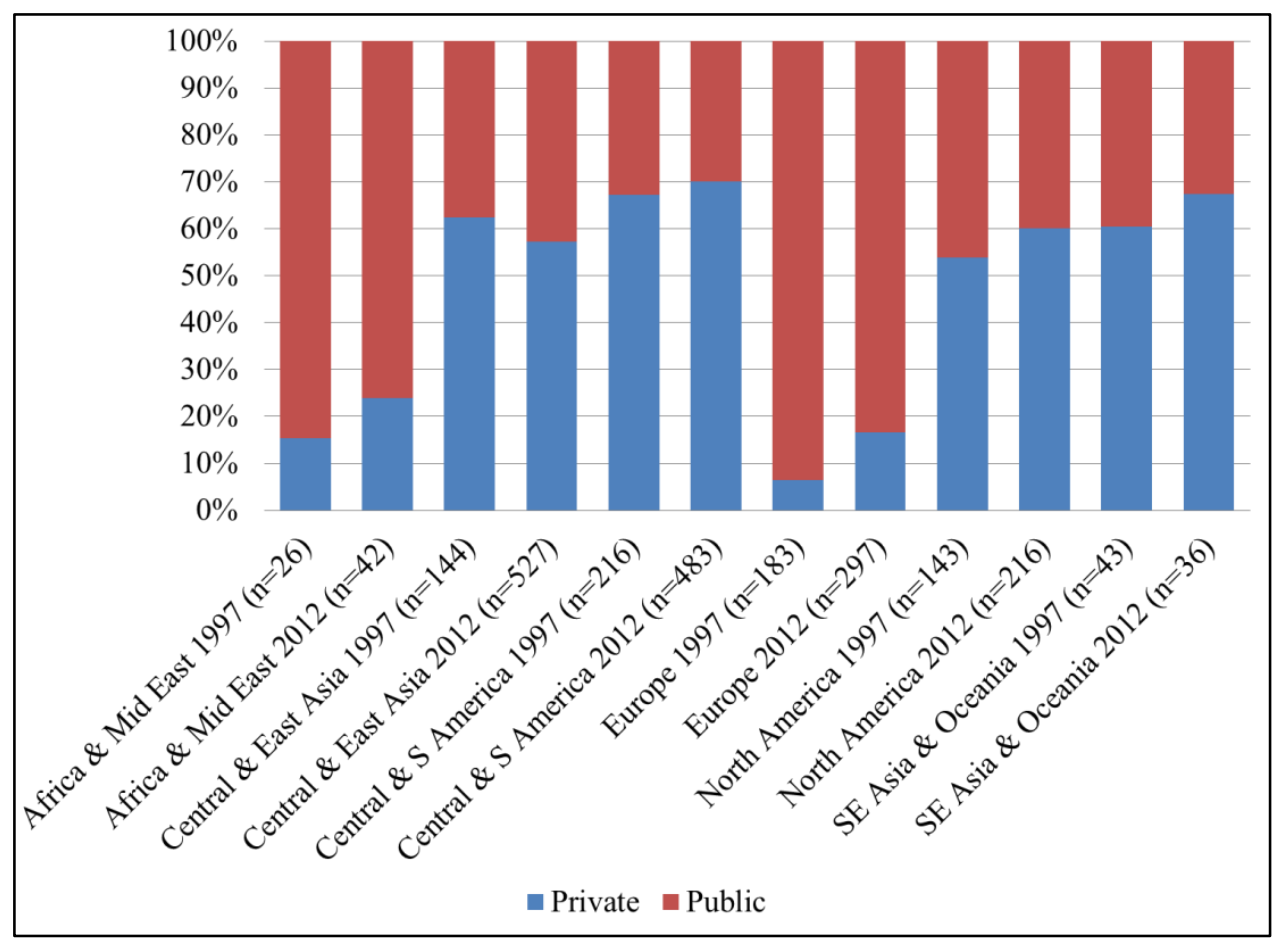

Figure 7. Number and Quality of Orthodontic Programs Per Region

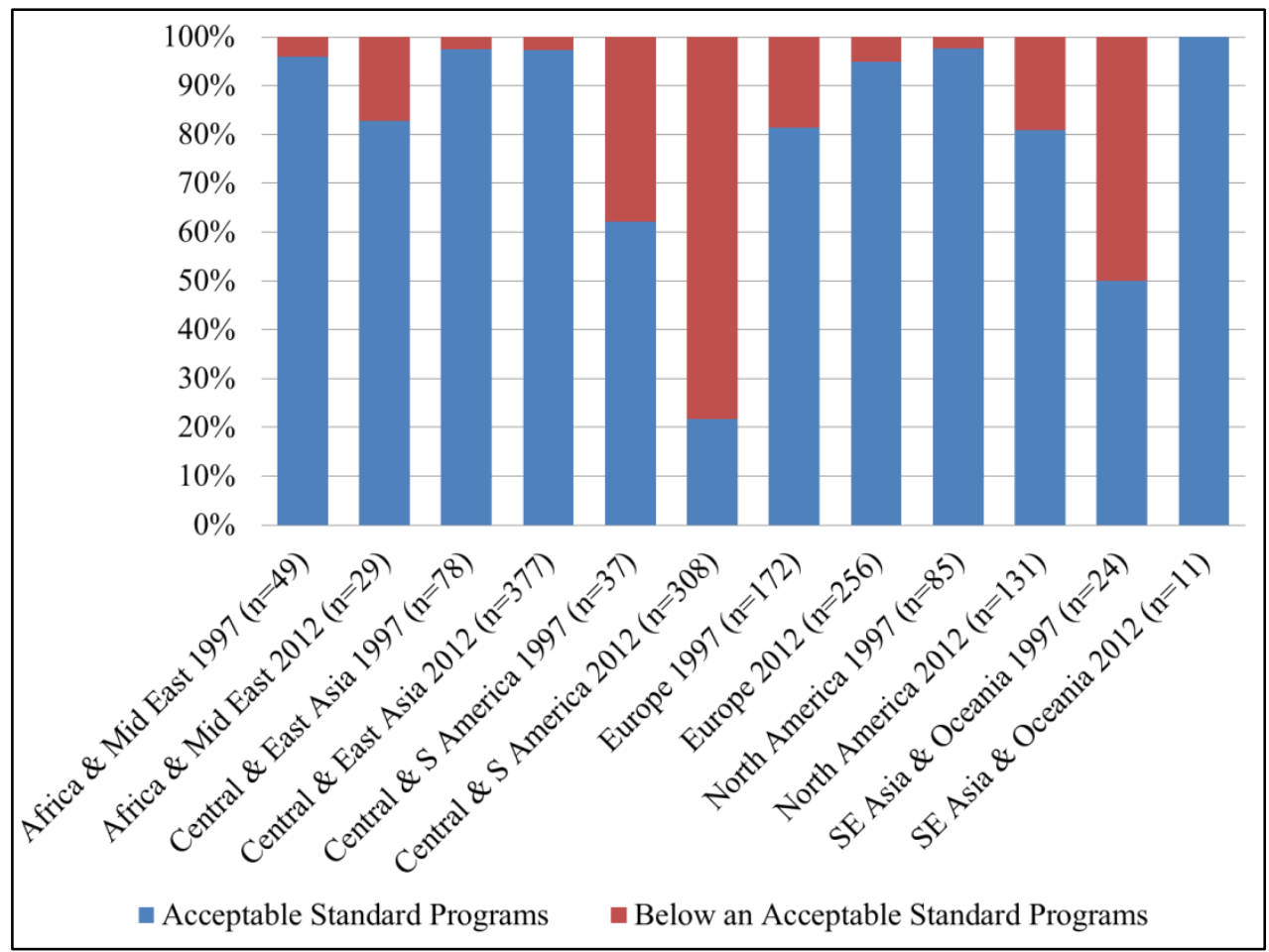


Figure 8. Percentage of Organizations in Countries with Accreditation Process for

Dental Schools and Postgraduate Orthodontic Programs

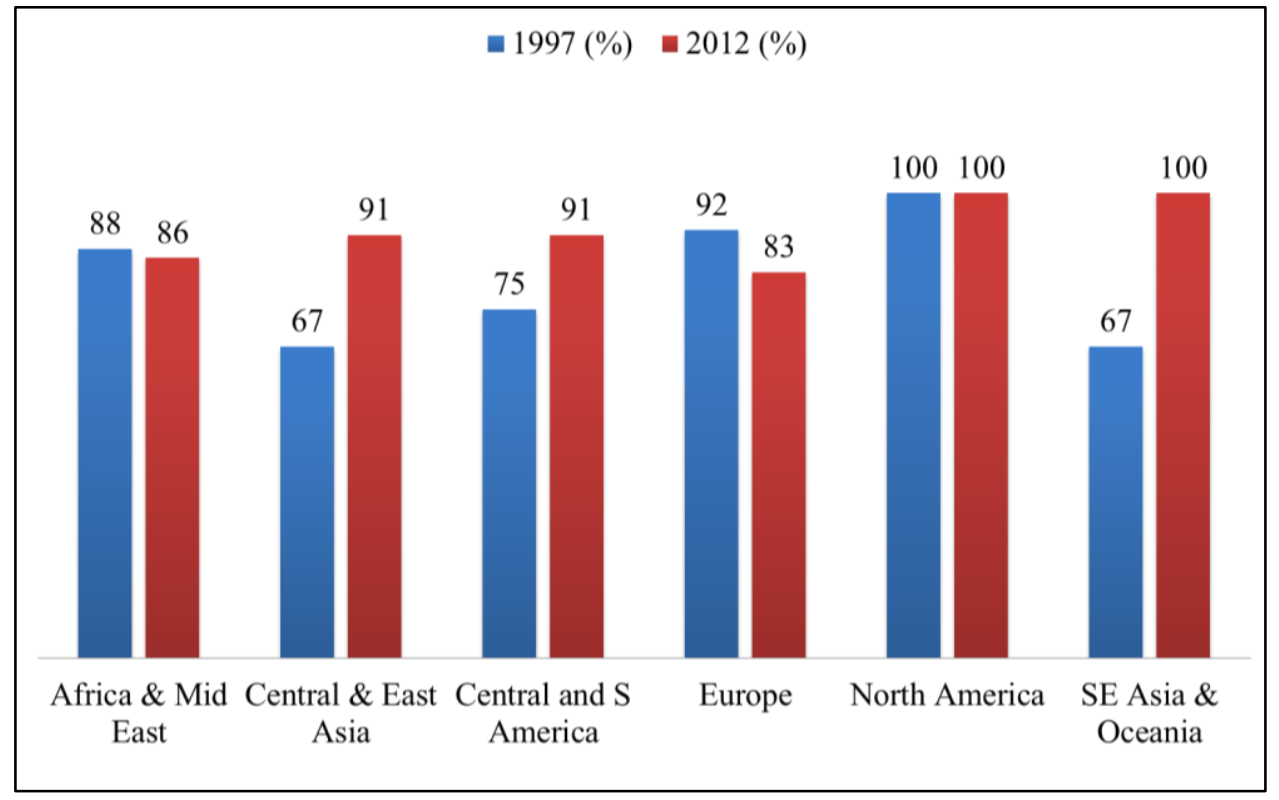

Figure 9. Percentage of Organizations in Countries Requiring Periodic Continuing

Education to Maintain Recognition as Orthodontist

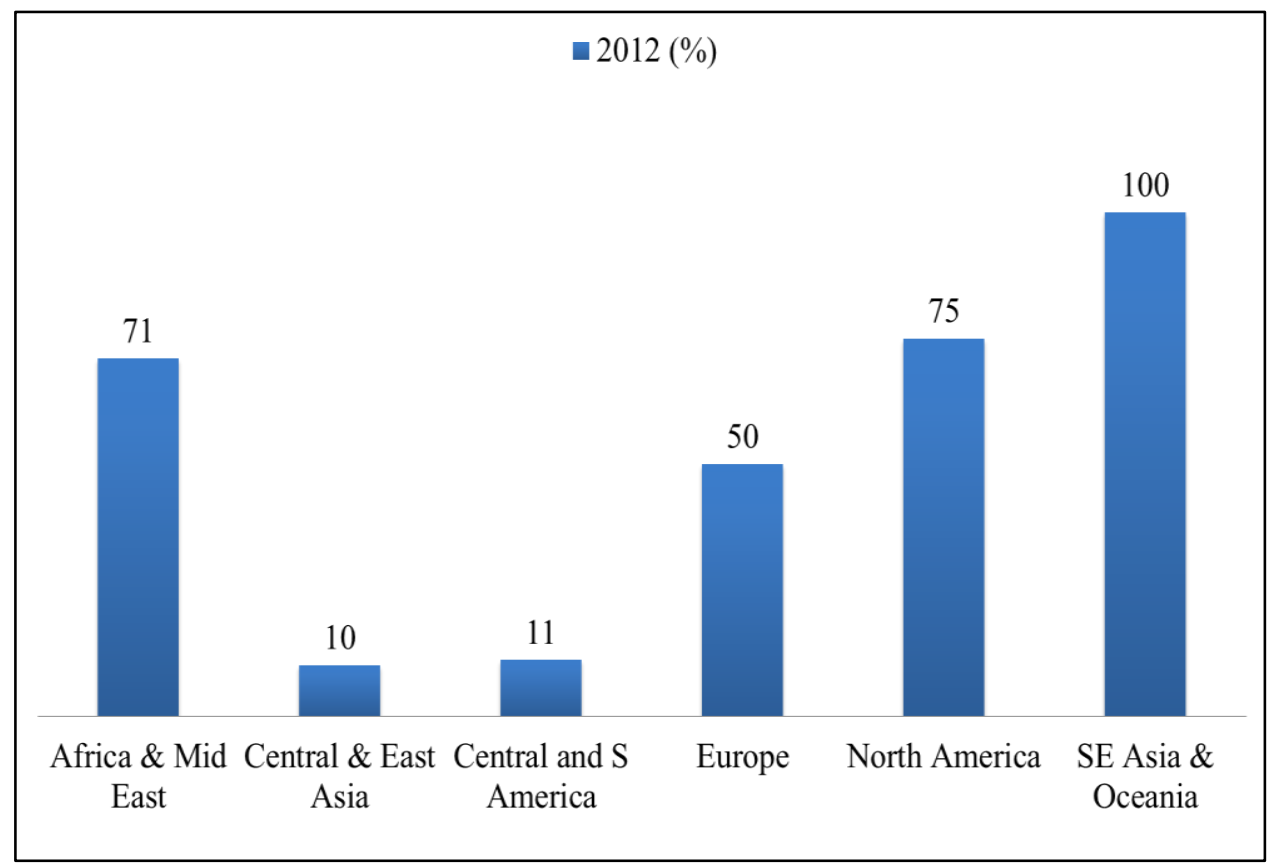


Figure 10. Percentage of Organizations Without a Certifying Board in Their

Country Who are Interested in How to Implement One

*North America has a certifying board in each of its countries.

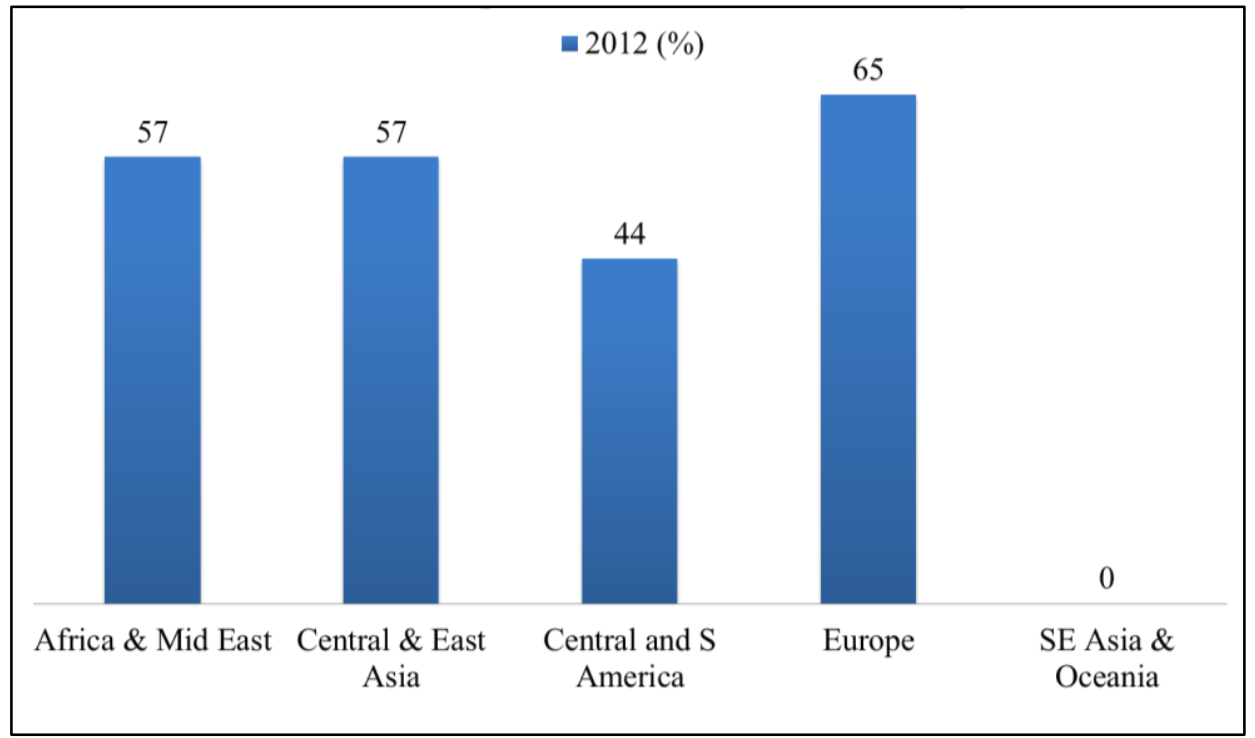

Figure 11. The Ratio of Orthodontists to General Dentists

*Each value represents the number of general dentists per orthodontist

- 2012

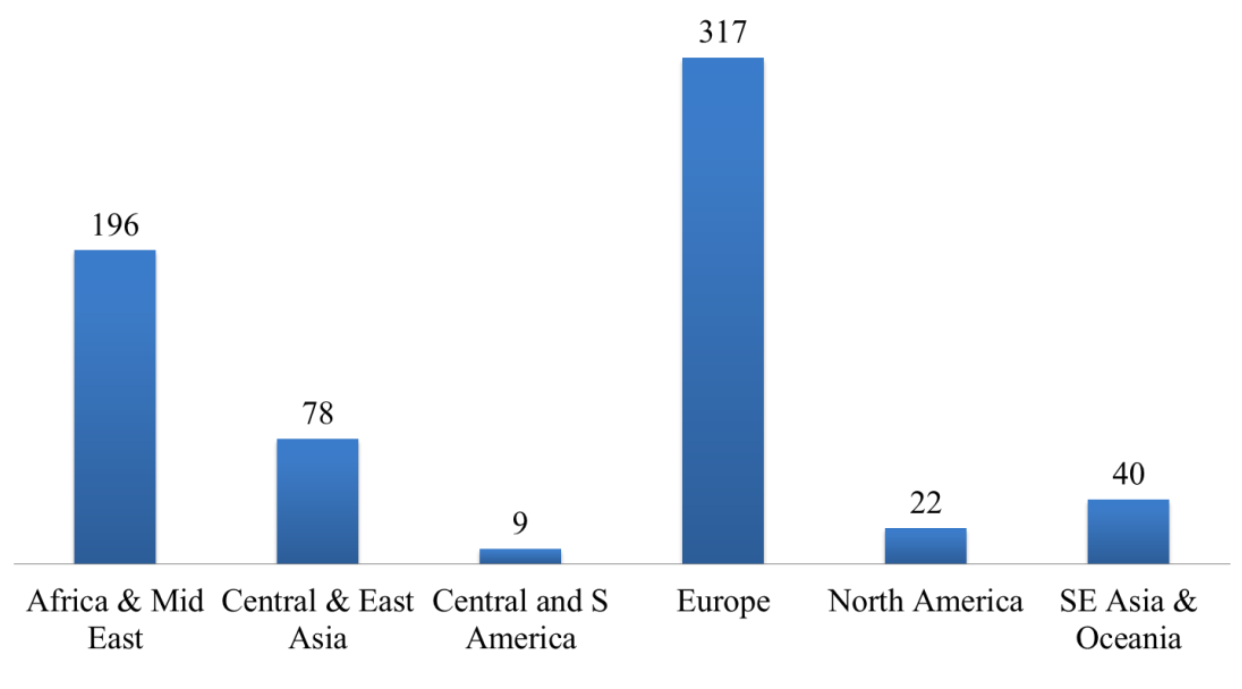


Figure 12. The Average Percentage of Orthodontists Practicing in a Particular Region Who Were Trained in That Region

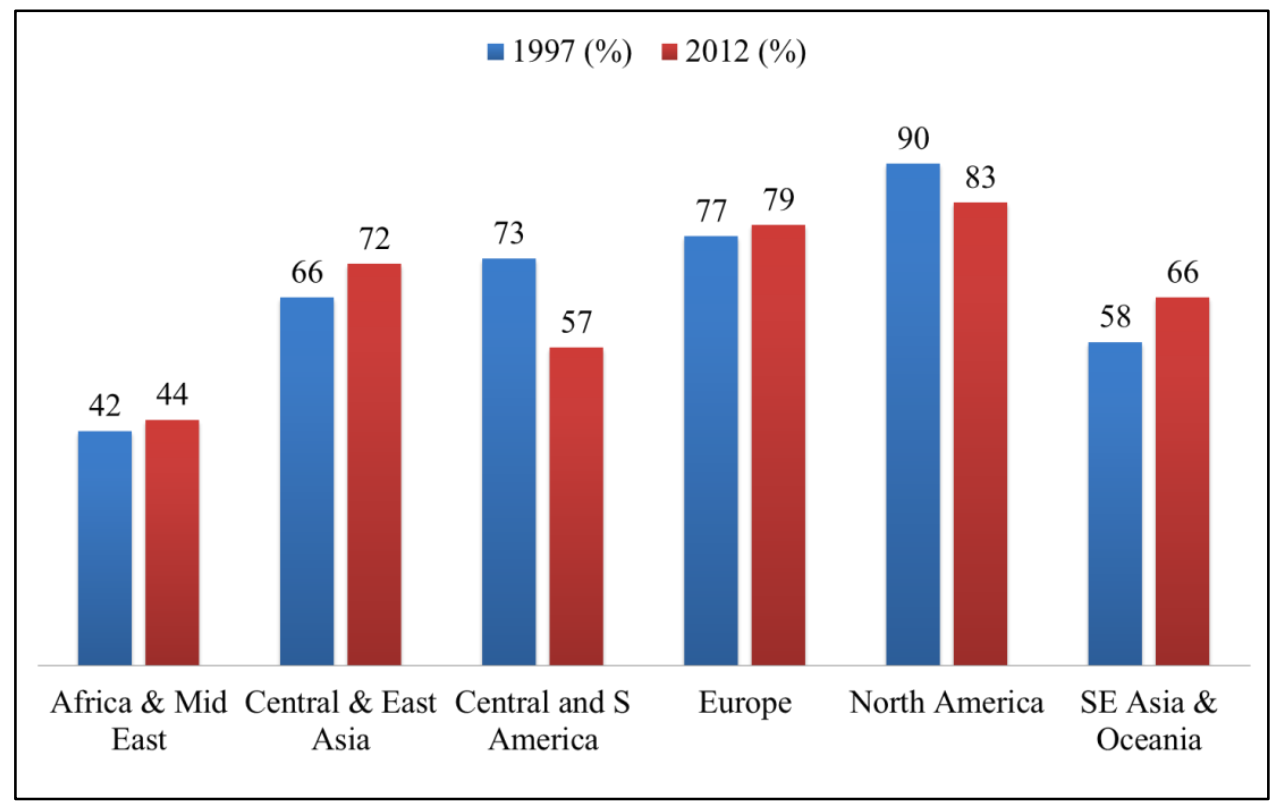

Figure 13. The Average Percentage of Orthodontists Trained in a Particular Region Who Continue Practicing in That Region

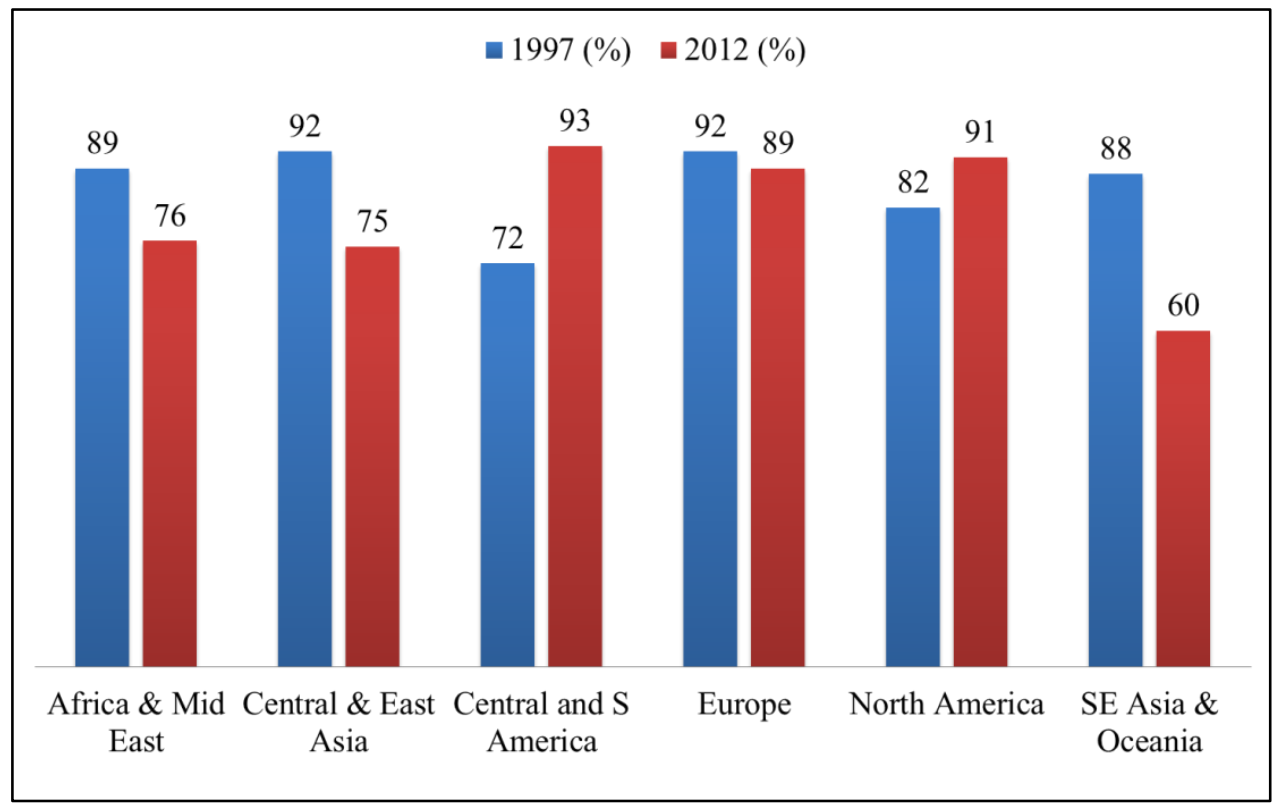


Figure 14. The Mean of the Percentage of Orthodontists Who Carry Malpractice Insurance

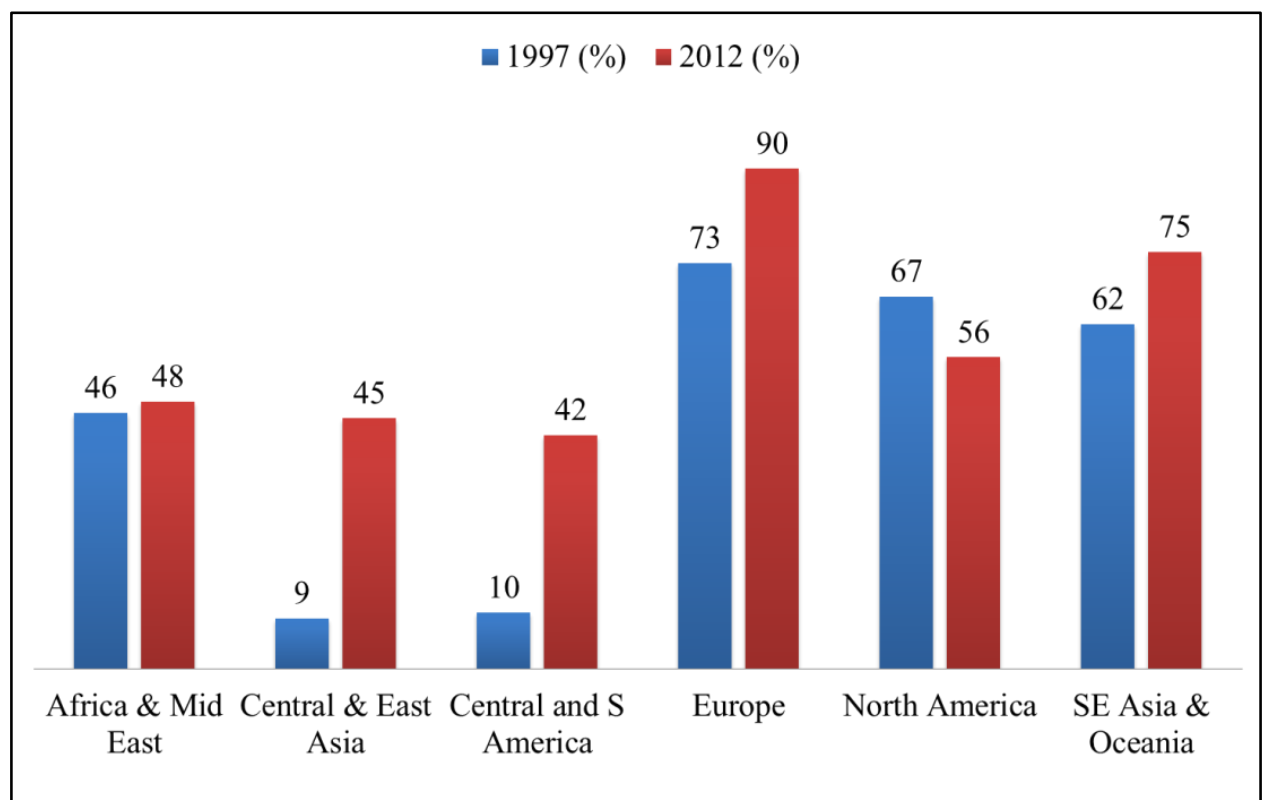

Figure 15. The Mean of the Percentage of Patients Treated with Comprehensive Orthodontics by an Orthodontist

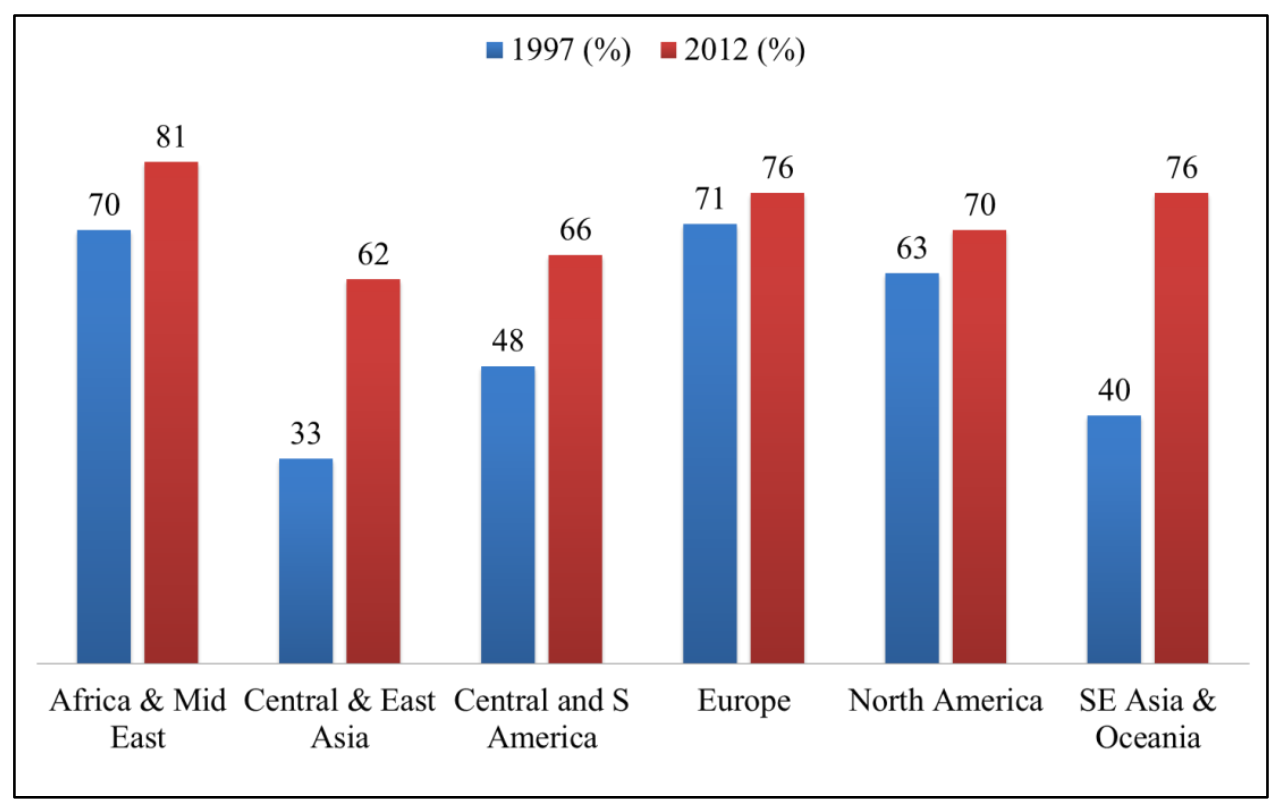


Figure 16. The Mean of the Percentage of Orthodontist-treated Patients Who are Adults (18 Years of Age or Older)

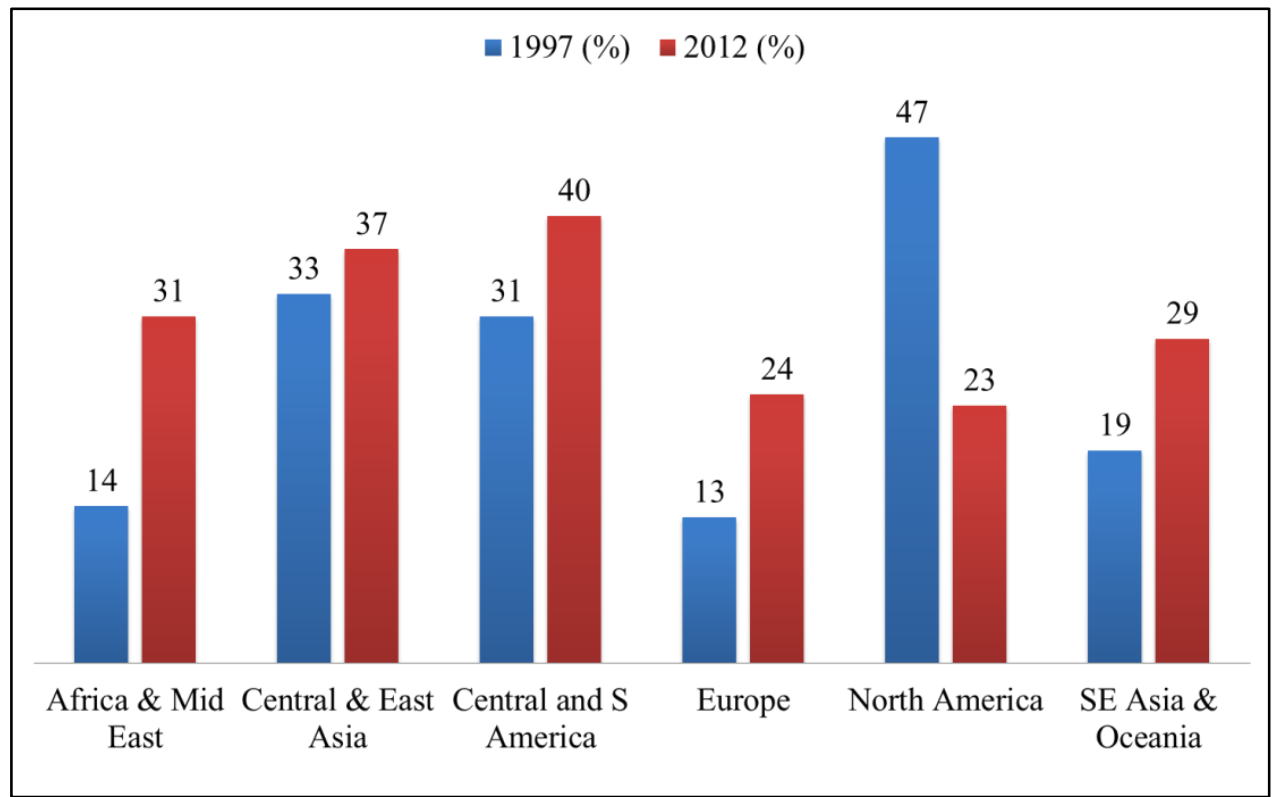

Figure 17. The Mean Number of National Organization Members Per Region

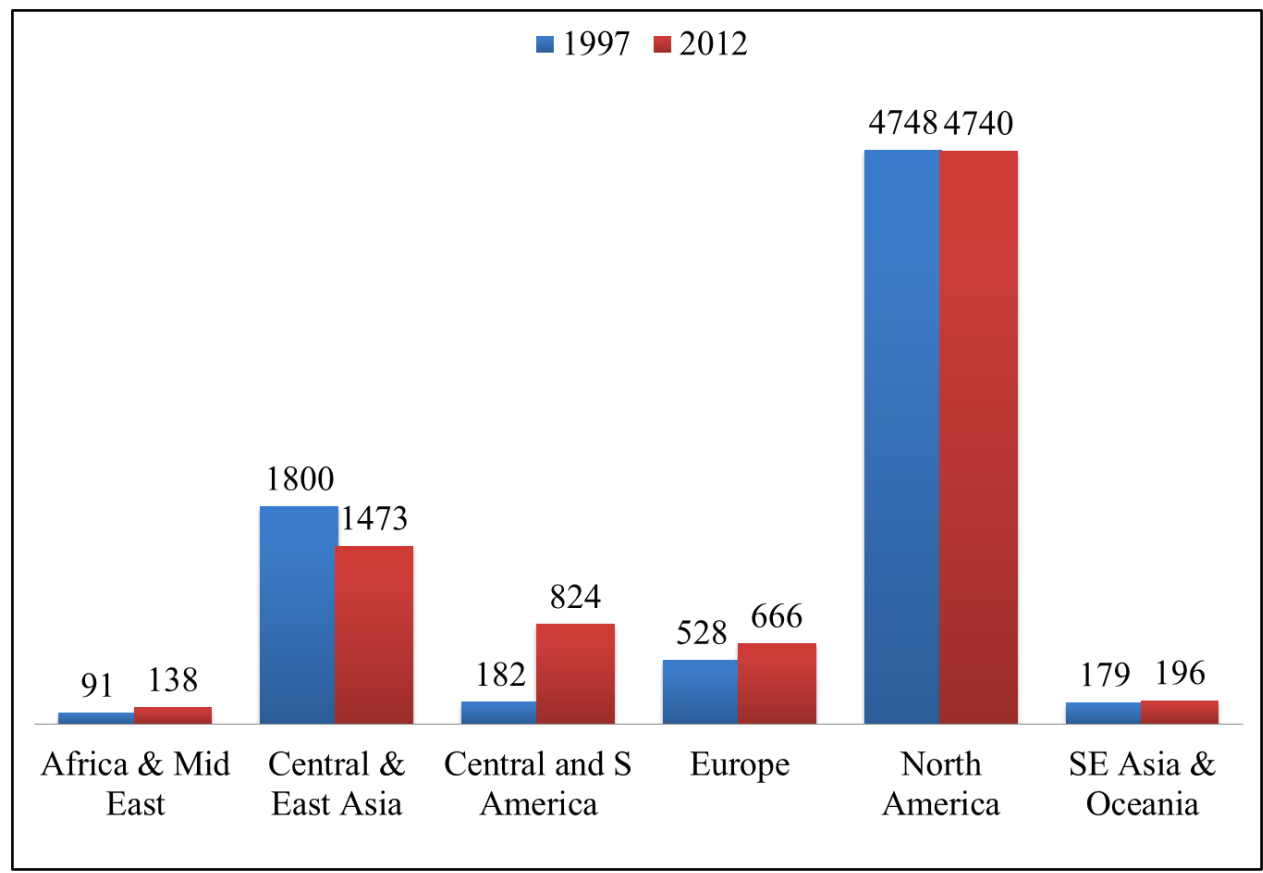


Figure 18. Percentage of Organizations Reporting There are Other Orthodontic Organizations in Their Country Not Affiliated with the WFO

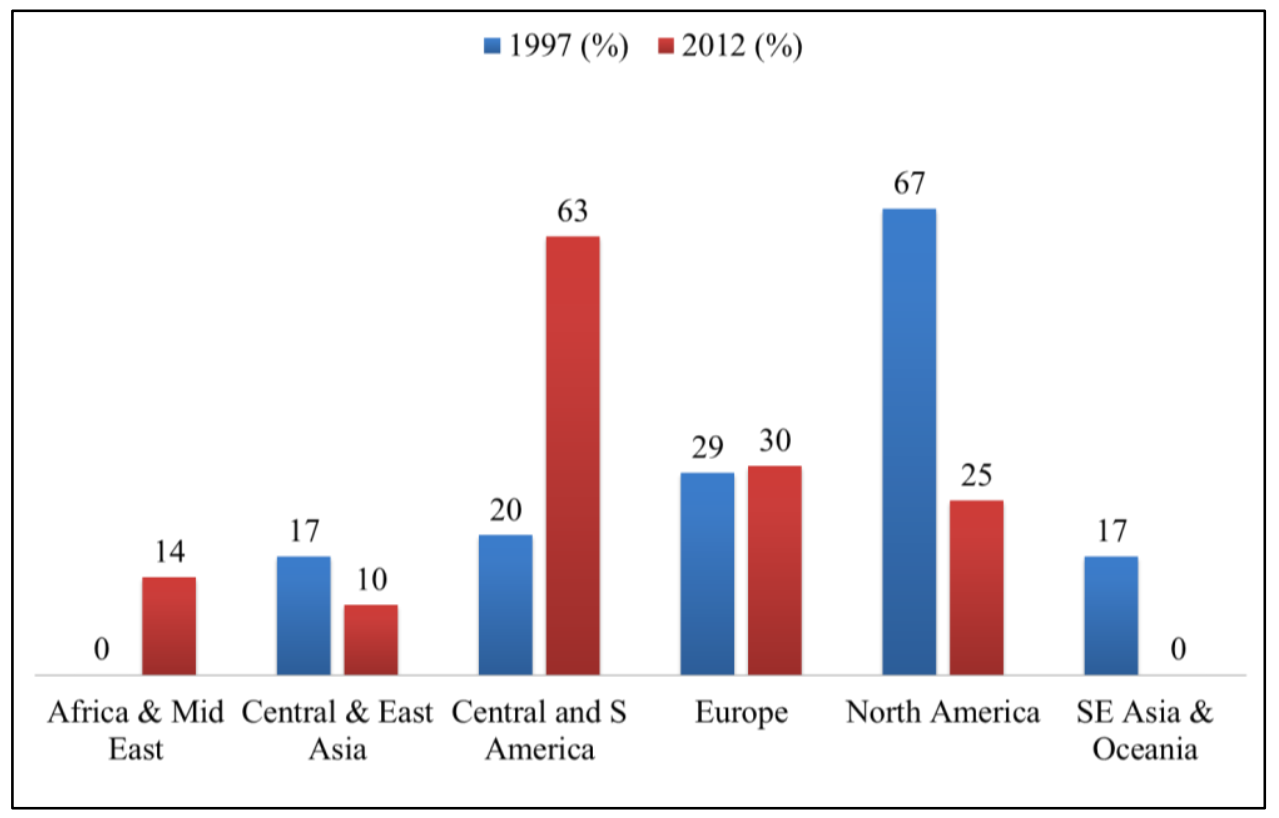

Figure 19. Percentage of Organizations That Limit Their Membership to Orthodontic Specialists

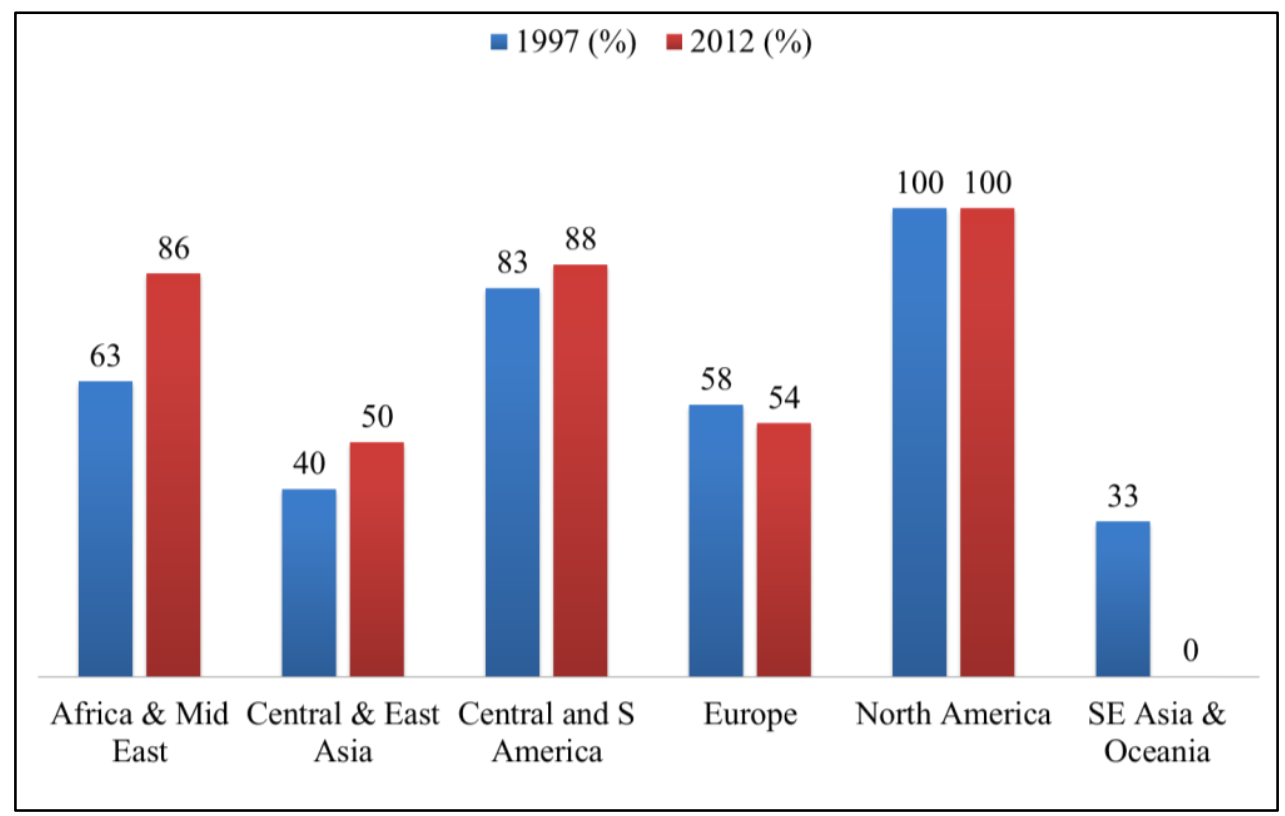


Figure 20. Percentage of Organizations Publishing Their Own Orthodontic Journal

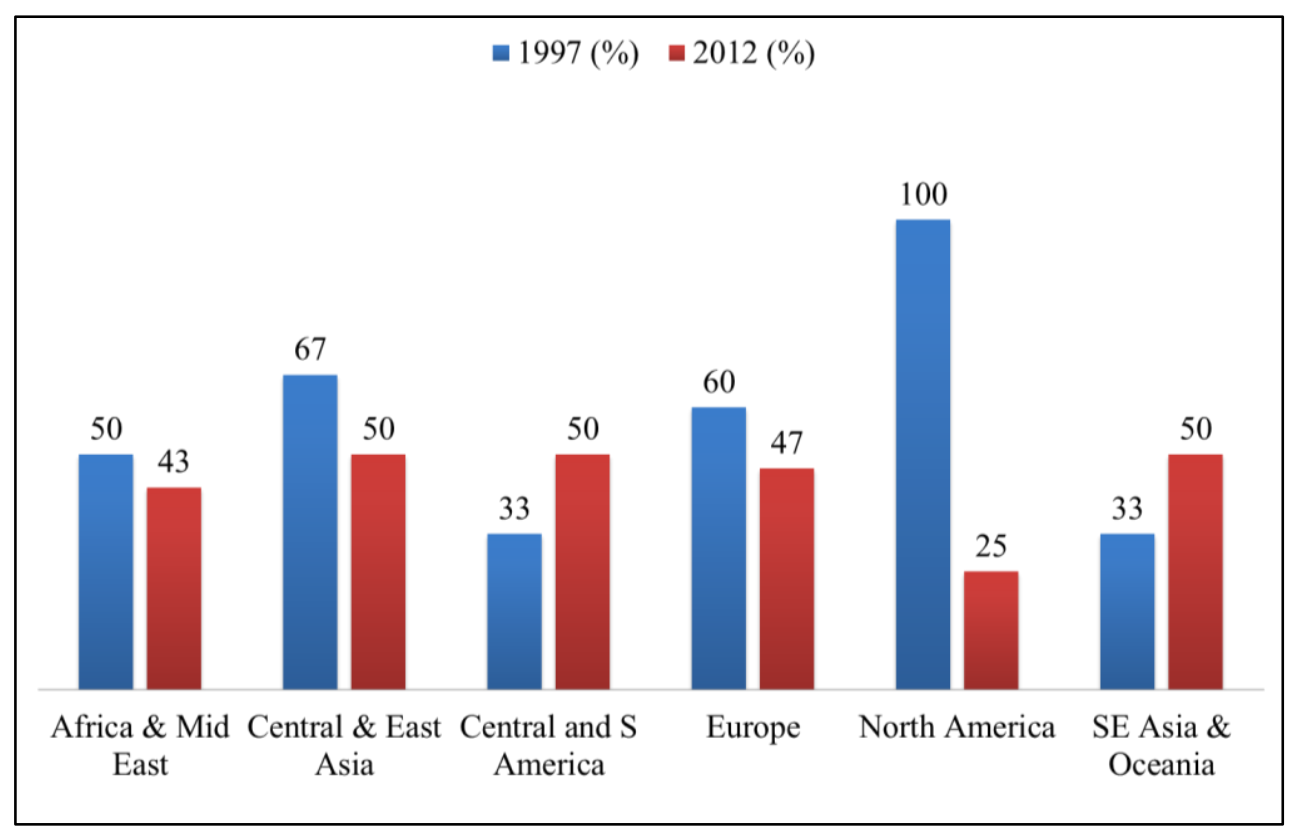




\section{TABLES}

Table 1. Required Length of Postgraduate Orthodontic Programs to Fulfill

Qualifications as an Orthodontic Specialist

*Mean Min column refers to the mean of reported minimum values

\begin{tabular}{|l|c|c|c|c|}
\hline \multicolumn{1}{|c|}{ Region } & \multicolumn{2}{|c|}{ Range } & \multicolumn{2}{|c|}{$\begin{array}{c}\text { Mean Min } \\
\text { (in months) }\end{array}$} \\
\hline & 1997 & 2012 & 1997 & 2012 \\
\hline Africa and Middle East & $20-42$ & $24-48$ & 31 & 36 \\
\hline Central and East Asia & $24-36$ & $24-72$ & 31 & 32 \\
\hline Central and South America & $6-30$ & $12-36$ & 22 & 20 \\
\hline Europe & $22-60$ & $24-48$ & 38 & 37 \\
\hline North America & $24-36$ & $24-36$ & 28 & 24 \\
\hline Southeast Asia \& Oceania & $24-36$ & $24-37$ & 33 & 33 \\
\hline
\end{tabular}


Table 2. Mean Percentage of Degrees and Certificates Awarded to Graduates of

\section{Orthodontic Programs}

\begin{tabular}{|l|c|c|c|c|c|c|}
\hline \multicolumn{1}{|c|}{ Regín } & \multicolumn{2}{|c|}{$\begin{array}{c}\text { Certificate of } \\
\text { completion }\end{array}$} & \multicolumn{2}{|c|}{$\begin{array}{c}\text { Master's } \\
\text { Degree }\end{array}$} & \multicolumn{2}{|c|}{ PhD } \\
\hline & $\mathbf{1 9 9 7}$ & $\mathbf{2 0 1 2}$ & $\mathbf{1 9 9 7}$ & $\mathbf{2 0 1 2}$ & $\mathbf{1 9 9 7}$ & $\mathbf{2 0 1 2}$ \\
\hline Africa and Middle East & $13 \%$ & $29 \%$ & $50 \%$ & $57 \%$ & $38 \%$ & 0 \\
\hline Central and East Asia & 0 & $80 \%$ & $50 \%$ & $80 \%$ & $50 \%$ & $20 \%$ \\
\hline Central and South America & $83 \%$ & $88 \%$ & $83 \%$ & $38 \%$ & $67 \%$ & $38 \%$ \\
\hline Europe & $76 \%$ & $74 \%$ & $16 \%$ & $41 \%$ & 0 & $19 \%$ \\
\hline North America & $100 \%$ & $100 \%$ & $100 \%$ & $100 \%$ & 0 & $50 \%$ \\
\hline Southeast Asia \& Oceania & $33 \%$ & $75 \%$ & $83 \%$ & $50 \%$ & $17 \%$ & 0 \\
\hline
\end{tabular}


Table 3. Percentage of Selected Options of Common Financial Arrangements for

Orthodontic Training

\begin{tabular}{|l|c|c|c|c|c|c|}
\hline \multicolumn{1}{|c|}{ Regín } & \multicolumn{2}{|c|}{ Pay Tuition } & \multicolumn{2}{|c|}{$\begin{array}{c}\text { Receive a } \\
\text { Stipend }\end{array}$} & $\begin{array}{c}\text { Practice Part- } \\
\text { time during }\end{array}$ \\
\hline & 1997 & $\mathbf{2 0 1 2}$ & $\mathbf{1 9 9 7}$ & $\mathbf{2 0 1 2}$ & $\mathbf{1 9 9 7}$ & $\mathbf{2 0 1 2}$ \\
\hline Africa and Middle East & $13 \%$ & $29 \%$ & $50 \%$ & $29 \%$ & $25 \%$ & $29 \%$ \\
\hline Central and East Asia & $83 \%$ & $80 \%$ & $67 \%$ & $50 \%$ & $17 \%$ & $30 \%$ \\
\hline Central and South America & $42 \%$ & $88 \%$ & $8 \%$ & $25 \%$ & $33 \%$ & $50 \%$ \\
\hline Europe & $56 \%$ & $72 \%$ & $44 \%$ & $48 \%$ & $48 \%$ & $17 \%$ \\
\hline North America & $100 \%$ & $100 \%$ & $33 \%$ & $100 \%$ & $33 \%$ & $75 \%$ \\
\hline Southeast Asia \& Oceania & $67 \%$ & $100 \%$ & $0 \%$ & $25 \%$ & $17 \%$ & 0 \\
\hline
\end{tabular}

Table 4. Percentage of Selected Options of Continuing Education Sources

\begin{tabular}{|c|c|c|c|c|c|}
\hline Region & $\begin{array}{l}\text { Delivered by } \\
\text { Own } \\
\text { Organization }\end{array}$ & $\begin{array}{l}\text { Delivered at } \\
\text { Other } \\
\text { Orthodontic } \\
\text { Specialty } \\
\text { Meetings }\end{array}$ & $\begin{array}{l}\text { Orthodontic } \\
\text { Journals }\end{array}$ & $\begin{array}{l}\text { Internet } \\
\text { Courses }\end{array}$ & $\begin{array}{l}\text { Study } \\
\text { Clubs }\end{array}$ \\
\hline Africa and Middle East & $86 \%$ & $86 \%$ & $43 \%$ & $14 \%$ & $14 \%$ \\
\hline Central and East Asia & $90 \%$ & $80 \%$ & $70 \%$ & $10 \%$ & $30 \%$ \\
\hline $\begin{array}{l}\text { Central and South } \\
\text { America }\end{array}$ & $100 \%$ & $100 \%$ & $75 \%$ & $25 \%$ & $50 \%$ \\
\hline Europe & $90 \%$ & $93 \%$ & $70 \%$ & $13 \%$ & $43 \%$ \\
\hline North America & $100 \%$ & $100 \%$ & $75 \%$ & $50 \%$ & $50 \%$ \\
\hline $\begin{array}{l}\text { Southeast Asia \& } \\
\text { Oceania }\end{array}$ & $75 \%$ & $100 \%$ & $100 \%$ & $25 \%$ & $100 \%$ \\
\hline
\end{tabular}


Table 5. National Certifying Boards on WFO Board Committee (Year Founded and

Percentage of National Organization Members Who are Board Certified)

\begin{tabular}{|l|c|c|}
\hline & Year Founded & $\begin{array}{c}\text { Percentage of } \\
\text { Organization Members } \\
\text { Certified }\end{array}$ \\
\hline American Board & 1929 & $45 \%$ \\
\hline Argentinian Board & 1980 & $20 \%$ \\
\hline Australian Board & 1999 & $30 \%$ \\
\hline Brazilian Board & 2000 & $4 \%$ \\
\hline French Board & 1995 & $2 \%$ \\
\hline German Board & 1993 & $5 \%$ \\
\hline Indian Board & 1998 & $10 \%$ \\
\hline Italian Board & 1999 & $3 \%$ \\
\hline Japanese Board & 2008 & $4 \%$ \\
\hline Korean Board & 2008 & $10 \%$ \\
\hline Mexican Board & 1995 & $28 \%$ \\
\hline Philippine Board & 1981 & $18 \%$ \\
\hline Taiwan Board & 1994 & $5 \%$ \\
\hline Thai Board & 1997 & $23 \%$ \\
\hline
\end{tabular}


Table 6. Characteristics of Board Examination Process

\begin{tabular}{|l|l|l|l|}
\hline & $\begin{array}{c}\text { Discussion of } \\
\text { Candidate's Own } \\
\text { Cases }\end{array}$ & Written Exam & $\begin{array}{c}\text { Evaluation of Case } \\
\text { Candidate Has Not } \\
\text { Seen }\end{array}$ \\
\hline American Board & $\mathbf{X}$ & $\mathbf{X}$ & $\mathbf{X}$ \\
\hline Argentinian Board & $\mathbf{X}$ & $\mathbf{X}$ & $\mathbf{X}$ \\
\hline Australian Board & $\mathbf{X}$ & $\mathbf{X}$ & \\
\hline Brazilian Board & $\mathbf{X}$ & $\mathbf{X}$ \\
\hline French Board & $\mathbf{X}$ & $\mathbf{X}$ & \\
\hline German Board & $\mathbf{X}$ & $\mathbf{X}$ & \\
\hline Indian Board & $\mathbf{X}$ & & \\
\hline Italian Board & $\mathbf{X}$ & $\mathbf{X}$ & \\
\hline Japanese Board & & $\mathbf{X}$ & $\mathbf{X}$ \\
\hline Korean Board & $\mathbf{X}$ & $\mathbf{X}$ & \\
\hline Mexican Board & $\mathbf{X}$ & $\mathbf{X}$ & \\
\hline Philippine Board & & & \\
\hline Taiwan Board & & & \\
\hline Thai Board & & & \\
\hline
\end{tabular}


Table 7. Mean Percentages of Who Orthodontists Practice With

\begin{tabular}{|l|c|c|c|c|}
\hline \multicolumn{1}{|c|}{ Region } & $\begin{array}{c}\text { Mean Percentage of } \\
\text { Orthodontists Practicing } \\
\text { Either By Themselves or } \\
\text { with Other Orthodontists }\end{array}$ & $\begin{array}{r}\text { Mean Percentage of } \\
\text { Orthodontists Practicing } \\
\text { with General Dentists or } \\
\text { Non-Orthodontic } \\
\text { Specialists }\end{array}$ \\
\hline Africa and Middle East & $\mathbf{1 9 9 7}$ & $\mathbf{2 0 1 2}$ & $\mathbf{1 9 9 7}$ & $\mathbf{2 0 1 2}$ \\
\hline Central and East Asia & $77 \%$ & $82 \%$ & $14 \%$ & $18 \%$ \\
\hline Central and South America & $78 \%$ & $72 \%$ & $23 \%$ & $28 \%$ \\
\hline Europe & $80 \%$ & $80 \%$ & $20 \%$ & $20 \%$ \\
\hline North America & $85 \%$ & $90 \%$ & $15 \%$ & $10 \%$ \\
\hline Southeast Asia \& Oceania & $61 \%$ & $89 \%$ & $39 \%$ & $11 \%$ \\
\hline
\end{tabular}

Table 8. Percentage of Selected Options of Orthodontic Treatment Financing Methods

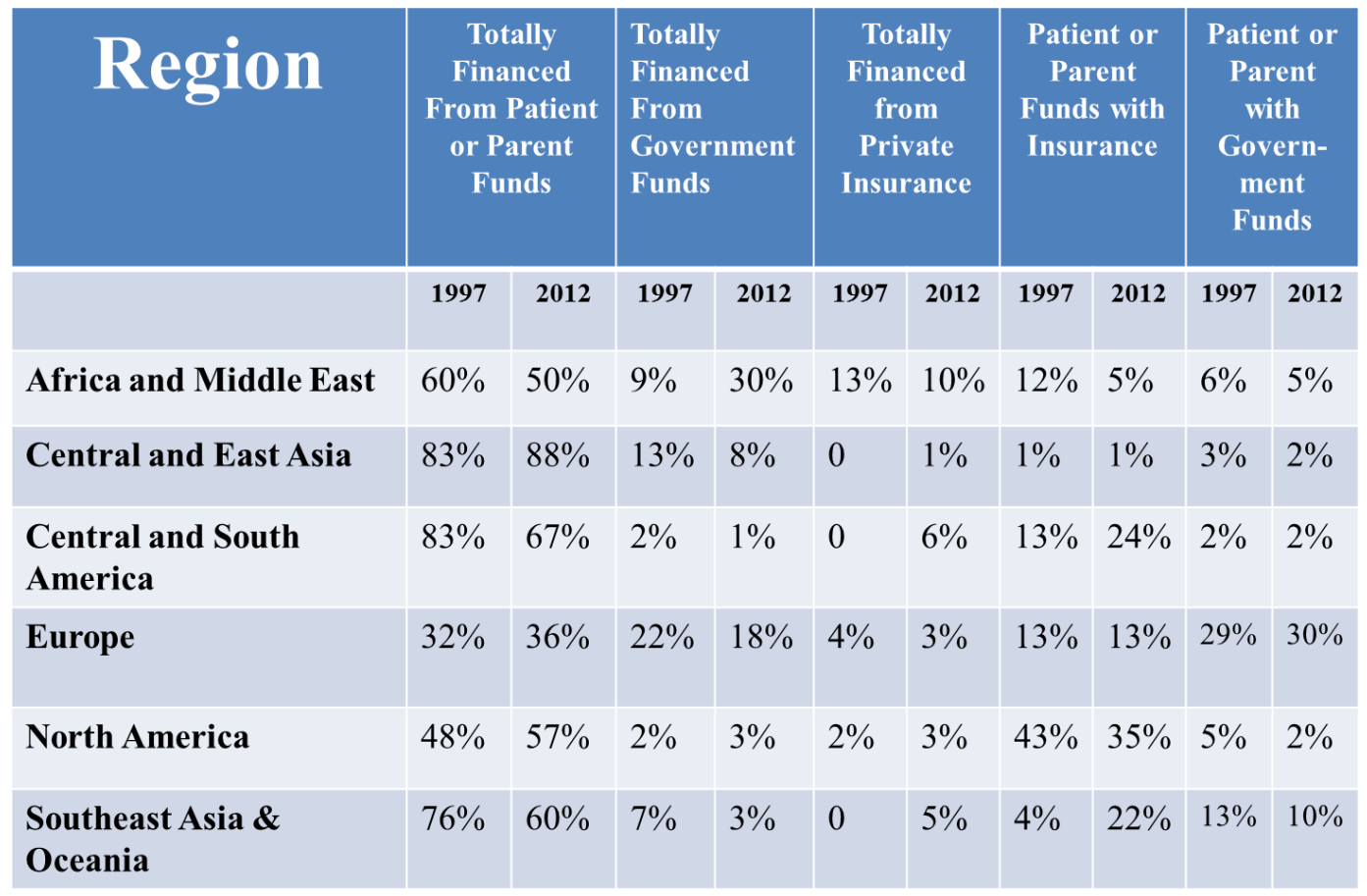


Table 9. Percentage of Orthodontists' Use of Fixed Appliance Alone, Removable Appliance Alone, and a Combination of Fixed and Removable Appliances

\begin{tabular}{|c|c|c|c|c|c|c|}
\hline Region & \multicolumn{2}{|c|}{$\begin{array}{c}\text { Fixed Appliance } \\
\text { Alone (To } \\
\text { Include } \\
\text { Headgear) }\end{array}$} & \multicolumn{2}{|c|}{$\begin{array}{c}\text { Removable } \\
\text { Appliance Alone }\end{array}$} & \multicolumn{2}{|c|}{$\begin{array}{c}\text { Combination } \\
\text { of Fixed and } \\
\text { Removable } \\
\text { Appliance }\end{array}$} \\
\hline & 1997 & 2012 & 1997 & 2012 & 1997 & 2012 \\
\hline Africa and Middle East & $60 \%$ & $63 \%$ & $20 \%$ & $14 \%$ & $20 \%$ & $23 \%$ \\
\hline Central and East Asia & $49 \%$ & $52 \%$ & $27 \%$ & $10 \%$ & $24 \%$ & $38 \%$ \\
\hline $\begin{array}{l}\text { Central and South } \\
\text { America }\end{array}$ & $51 \%$ & $66 \%$ & $25 \%$ & $12 \%$ & $24 \%$ & $22 \%$ \\
\hline Europe & $35 \%$ & $48 \%$ & $40 \%$ & $17 \%$ & $25 \%$ & $35 \%$ \\
\hline North America & $80 \%$ & $70 \%$ & $5 \%$ & $9 \%$ & $15 \%$ & $21 \%$ \\
\hline Southeast Asia \& Oceania & $82 \%$ & $71 \%$ & $6 \%$ & $10 \%$ & $12 \%$ & $19 \%$ \\
\hline
\end{tabular}

Table 10. Percentage of Prevalence of Temporary Anchorage Device* Use

*To include miniscrews and bone anchors

\begin{tabular}{|l|c|c|c|c|}
\hline \multicolumn{1}{|c|}{ Region } & $\begin{array}{c}\text { No } \\
\text { Orthodontists } \\
\text { Use It }\end{array}$ & $\begin{array}{c}\text { A Few } \\
\text { Orthodontists } \\
\text { Use It }\end{array}$ & $\begin{array}{c}\text { Some } \\
\text { Orthodontists } \\
\text { Use It }\end{array}$ & $\begin{array}{c}\text { Most } \\
\text { Orthodontist } \\
\text { s Use It }\end{array}$ \\
\hline Africa and Middle East & $14 \%$ & $29 \%$ & $57 \%$ & 0 \\
\hline Central and East Asia & $10 \%$ & 0 & $50 \%$ & $40 \%$ \\
\hline Central and South America & 0 & $25 \%$ & $62 \%$ & $13 \%$ \\
\hline Europe & 0 & $24 \%$ & $59 \%$ & $17 \%$ \\
\hline North America & 0 & 0 & $75 \%$ & $25 \%$ \\
\hline Southeast Asia \& Oceania & 0 & $25 \%$ & $75 \%$ & 0 \\
\hline
\end{tabular}


Table 11. Percentage of Prevalence of Lingual Fixed Orthodontic Appliance Use

\begin{tabular}{|l|c|c|c|c|}
\hline \multicolumn{1}{|c|}{ | } & $\begin{array}{c}\text { No } \\
\text { Orthodontists } \\
\text { Use It }\end{array}$ & $\begin{array}{c}\text { A Few } \\
\text { Orthodontists } \\
\text { Use It }\end{array}$ & $\begin{array}{c}\text { Some } \\
\text { Orthodontists } \\
\text { Use It }\end{array}$ & $\begin{array}{c}\text { Most } \\
\text { Orthodontist } \\
\text { s Use It }\end{array}$ \\
\hline Africa and Middle East & $14 \%$ & $86 \%$ & 0 & 0 \\
\hline Central and East Asia & $10 \%$ & $30 \%$ & $60 \%$ & 0 \\
\hline Central and South America & 0 & $87 \%$ & $13 \%$ & 0 \\
\hline Europe & 0 & $72 \%$ & $28 \%$ & 0 \\
\hline North America & 0 & $75 \%$ & $25 \%$ & 0 \\
\hline Southeast Asia \& Oceania & 0 & $75 \%$ & $25 \%$ & 0 \\
\hline
\end{tabular}

Table 12. Percentage of Prevalence of Clear Aligner Therapy Use

\begin{tabular}{|l|c|c|c|c|}
\hline \multicolumn{1}{|c|}{ Region } & $\begin{array}{c}\text { No } \\
\text { Orthodontists } \\
\text { Use It }\end{array}$ & $\begin{array}{c}\text { A Few } \\
\text { Orthodontists } \\
\text { Use It }\end{array}$ & $\begin{array}{c}\text { Some } \\
\text { Orthodontists } \\
\text { Use It }\end{array}$ & $\begin{array}{c}\text { Most } \\
\text { Orthodontist } \\
\text { s Use It }\end{array}$ \\
\hline Africa and Middle East & 0 & $86 \%$ & $14 \%$ & 0 \\
\hline Central and East Asia & $20 \%$ & $40 \%$ & $30 \%$ & $10 \%$ \\
\hline Central and South America & 0 & $50 \%$ & $50 \%$ & 0 \\
\hline Europe & $10 \%$ & $55 \%$ & $35 \%$ & 0 \\
\hline North America & 0 & $50 \%$ & $25 \%$ & $25 \%$ \\
\hline Southeast Asia \& Oceania & 0 & 0 & $100 \%$ & 0 \\
\hline
\end{tabular}


Table 13. Percentage of Prevalence of Laser Device Use

\begin{tabular}{|l|c|c|c|c|}
\hline \multicolumn{1}{|c|}{} & $\begin{array}{c}\text { No } \\
\text { Orthodontists } \\
\text { Use It }\end{array}$ & $\begin{array}{c}\text { A Few } \\
\text { Orthodontists } \\
\text { Use It }\end{array}$ & $\begin{array}{c}\text { Some } \\
\text { Orthodontists } \\
\text { Use It }\end{array}$ & $\begin{array}{c}\text { Most } \\
\text { Orthodontist } \\
\text { s Use It }\end{array}$ \\
\hline Africa and Middle East & $43 \%$ & $57 \%$ & 0 & 0 \\
\hline Central and East Asia & $40 \%$ & $60 \%$ & 0 & 0 \\
\hline Central and South America & 0 & $50 \%$ & $50 \%$ & 0 \\
\hline Europe & $13 \%$ & $87 \%$ & 0 & 0 \\
\hline North America & & & & 0 \\
\hline Southeast Asia \& Oceania & $25 \%$ & $75 \%$ & $00 \%$ & 0 \\
\hline
\end{tabular}

Table 14. Percentage of Prevalence of Cone Beam Computed Tomography Use

\begin{tabular}{|l|c|c|c|c|}
\hline \multicolumn{1}{|c|}{ Region } & $\begin{array}{c}\text { No } \\
\text { Orthodontists } \\
\text { Use It }\end{array}$ & $\begin{array}{c}\text { A Few } \\
\text { Orthodontists } \\
\text { Use It }\end{array}$ & $\begin{array}{c}\text { Some } \\
\text { Orthodontists } \\
\text { Use It }\end{array}$ & $\begin{array}{c}\text { Most } \\
\text { Orthodontist } \\
\text { s Use It }\end{array}$ \\
\hline Africa and Middle East & $29 \%$ & $42 \%$ & $29 \%$ & 0 \\
\hline Central and East Asia & $30 \%$ & $30 \%$ & $40 \%$ & 0 \\
\hline Central and South America & 0 & $62 \%$ & $25 \%$ & $13 \%$ \\
\hline Europe & $10 \%$ & $52 \%$ & $28 \%$ & $10 \%$ \\
\hline North America & 0 & $50 \%$ & $50 \%$ & 0 \\
\hline Southeast Asia \& Oceania & 0 & $50 \%$ & $50 \%$ & 0 \\
\hline
\end{tabular}




\section{Table 15. The Ranking of Common Reasons for Temporary Anchorage Device Use}

*Value of 4 being the most common reason and 1 being the least common reason

**North America and Southeast Asia and Oceania feature equal values in the unmarked cells

\begin{tabular}{|l|c|c|c|c|}
\hline \multicolumn{1}{|c|}{ Region } & $\begin{array}{c}\text { Anchorage for } \\
\text { Space Closure }\end{array}$ & $\begin{array}{c}\text { Aid in Class II } \\
\text { Correction }\end{array}$ & $\begin{array}{c}\text { Special } \\
\text { Situations } \\
\text { (Cants, } \\
\text { Asymmetries) }\end{array}$ & $\begin{array}{c}\text { Aid in Class } \\
\text { III Growth } \\
\text { Modification }\end{array}$ \\
\hline Africa and Middle East & 4 & 3 & 2 & 1 \\
\hline Central and East Asia & 4 & 3 & 2 & 1 \\
\hline Central and South America & 4 & 3 & 2 & 1 \\
\hline Europe & 4 & 3 & 2 & 1 \\
\hline North America & 4 & $*$ & $*$ & $*$ \\
\hline Southeast Asia \& Oceania & $*$ & $*$ & 3 & 4 \\
\hline
\end{tabular}


Table 16. The Ranking of Common Reasons for Cone Beam Computed

Tomography

*Value of 5 being the most common and 1 being the least common reason

**North America and Southeast Asia and Oceania feature equal values in the unmarked cells

\begin{tabular}{|c|c|c|c|c|c|}
\hline Region & $\begin{array}{l}\text { Locate } \\
\text { Impacted } \\
\text { Teeth }\end{array}$ & $\begin{array}{c}\text { Plan } \\
\text { Orthognathic } \\
\text { Surgery }\end{array}$ & $\begin{array}{c}\text { Examine } \\
\text { Patient } \\
\text { Airway }\end{array}$ & $\begin{array}{l}\text { Treatment } \\
\text { Plan Routine } \\
\text { Orthodontics }\end{array}$ & $\begin{array}{c}\text { Fabricate } \\
\text { Custom } \\
\text { Brackets } \\
\text { and Wires }\end{array}$ \\
\hline Africa and Middle East & 5 & 4 & 3 & 1 & 2 \\
\hline Central and East Asia & 5 & 4 & 2 & 3 & 1 \\
\hline $\begin{array}{l}\text { Central and South } \\
\text { America }\end{array}$ & 5 & 4 & 2 & 3 & 1 \\
\hline Europe & 5 & 4 & 3 & 2 & 1 \\
\hline North America & 5 & $*$ & $*$ & $*$ & $*$ \\
\hline $\begin{array}{l}\text { Southeast Asia \& } \\
\text { Oceania }\end{array}$ & 5 & 4 & 3 & $*$ & $*$ \\
\hline
\end{tabular}




\section{References}

1. Graber LW. The world federation of orthodontists: Work in progress. Prog Orthod. 2005;6(2):136-139.

2. DeKock WH. A WFO-commissioned study provides data on the specialty's current characteristics and standards. WFO Gazette. 2000;5(2):1.

3. Athanasiou AE, Darendeliler MA, Eliades T, et al. World federation of orthodontists (WFO) guidelines for postgraduate orthodontic education. World J Orthod.

2009;10(2):153-166.

4. Kassel J, editor. Guidelines to aid in setting up national, regional certifying boards. WFO Gazette. 2009;14(1):1.

5. Bedair TM, Thompson S, Gupta C, Beck FM, Firestone AR. Orthodontists' opinions of factors affecting patients' choice of orthodontic practices. Am J Orthod Dentofacial Orthop. 2010;138(1):6.e1-7; discussion 6-7.

6. Brown BR, Inglehart MR. Orthodontic care for underserved patients: Professional attitudes and behavior of orthodontic residents and orthodontists. Angle Orthod.

2011;81(6):1090-1096.

7. Burke B, Hamdan AM, Tufekci E, Shroff B, Best AM, Lindauer SJ. Perceptions of soft tissue laser use in orthodontics. Angle Orthod. 2012;82(1):75-83.

8. Madhavji A, Araujo EA, Kim KB, Buschang PH. Attitudes, awareness, and barriers toward evidence-based practice in orthodontics. Am J Orthod Dentofacial Orthop. 2011;140(3):309-16.e2.

9. Pratt MC, Kluemper GT, Hartsfield JK,Jr, Fardo D, Nash DA. Evaluation of retention protocols among members of the american association of orthodontists in the united states. Am J Orthod Dentofacial Orthop. 2011;140(4):520-526.

10. van der Linden FP. Three years postgraduate programme in orthodontics: final report ERASMUS project. J Ir Dent Assoc. 1992;38(1):7-14.

11. Maruo IT, Colucci MG, Vieira S, Tanaka O, Camargo ES, Maruo H. Study of the legality of orthodontic practice by general practice dentists. R Dental Press Ortodon Ortop Facial. 2009;14(6):42.

12. Klein KP, Hannum WM, Koroluk LD, Proffit WR. Interactive distance learning for orthodontic residents: utilization and acceptability. Am J Orthod Dentofacial Orthop. 2012 Mar;141(3):378-85. 
13. Proffit WR, Fields HW, Sarver DM. Contemporary Orthodontics. $5^{\text {th }}$ ed. St. Louis: Mosby; 2012. 